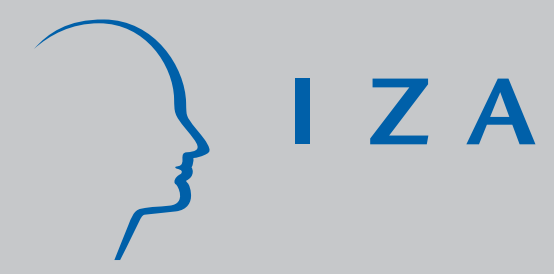

IZADP No. 2181

Wage Dispersion, Markets and Institutions:

The Effects of the Boom in Education on the Wage Structure

Erling Barth

Claudio Lucifora

J une 2006 


\title{
Wage Dispersion, Markets and Institutions: The Effects of the Boom in Education on the Wage Structure
}

\author{
Erling Barth \\ Institute for Social Research, \\ University of Oslo and IZA Bonn \\ Claudio Lucifora \\ Catholic University of Milan, \\ ERMES and IZA Bonn
}

Discussion Paper No. 2181 June 2006

\author{
IZA \\ P.O. Box 7240 \\ 53072 Bonn \\ Germany \\ Phone: +49-228-3894-0 \\ Fax: +49-228-3894-180 \\ Email: iza@iza.org
}

\begin{abstract}
Any opinions expressed here are those of the author(s) and not those of the institute. Research disseminated by IZA may include views on policy, but the institute itself takes no institutional policy positions.

The Institute for the Study of Labor (IZA) in Bonn is a local and virtual international research center and a place of communication between science, politics and business. IZA is an independent nonprofit company supported by Deutsche Post World Net. The center is associated with the University of Bonn and offers a stimulating research environment through its research networks, research support, and visitors and doctoral programs. IZA engages in (i) original and internationally competitive research in all fields of labor economics, (ii) development of policy concepts, and (iii) dissemination of research results and concepts to the interested public.
\end{abstract}

IZA Discussion Papers often represent preliminary work and are circulated to encourage discussion. Citation of such a paper should account for its provisional character. A revised version may be available directly from the author. 


\section{ABSTRACT \\ Wage Dispersion, Markets and Institutions: The Effects of the Boom in Education on the Wage Structure}

In this paper, we investigate the effects of the boom in education on the wage structure in Europe. We use detailed information on the distribution of wages, estimated from microdata from 12 European countries from the beginning of the 1980's to the present, to analyse the changes both between and within groups. We specify and estimate a model with supply and demand for different types of labour, as well as institutions affecting the bargained relative wage. Our results show that the boom in education closely matched the shifts in demand due to (skill biased) technological change, which in turn explains why the wage premia for education only rose moderately. We use the conditional wage spread within tertiary education, predicted from quantile log wage regressions, to investigate the hypothesis of skills erosion as a result of the large expansion in tertiary education. We find no evidence in favour of the hypothesis that the boom in higher education lead to an erosion of skills within the group of tertiary education, nor evidence of increasing "over-education" in Europe. Labour market institutions also matter: bargaining co-ordination and employment protection are shown to have a compressing effect on wages, but at different points of the wage distribution.

JEL Classification: J3, J5, P5

Keywords: wage inequality, education, labour market institutions

Corresponding author:

Claudio Lucifora

Università Cattolica

Largo Gemelli 1

20123 Milano

Italy

E-mail: claudio.lucifora@unicatt.it

\footnotetext{
* This paper is part of the project "Education and Wage Inequality in Europe" [EDWIN]. Financial support from the European Commission under the $V$ framework research project [contract number: HPSE-CT-2002-00108] is gratefully acknowledged. Data on wages have been kindly provided by project partners, while M. Wallerstein, Oecd and L. Nunziata have kindly supplied us with data on institutions. We are particularly grateful to $P$. Tzakloglou for extensive comments and suggestions on earlier drafts. Previous versions of this paper have been presented at the II EALE-SOLE World Conference (San Francisco) and in seminars at the University of Oslo and the University of Aarhus. Usual disclaimers apply.
} 


\section{Introduction}

In recent decades European countries have experienced a significant expansion in educational attainment and in particular in tertiary education. This boom in education has represented a considerable (supply) shock to the European labour markets and, as such, is expected to have had a considerable impact on the structure of wage differentials. In the US an extensive literature has documented the effects of market factors and institutions on the changes in wage inequality, and the driving forces behind those changes have been widely debated - i.e. shifts in the demand and supply of skills versus erosion of labour market institutions (Autor et al, 1998; Acemoglu, 2002; Card and DiNardo, 2002 and Autor et al, 2005). The evolution of wage dispersion in Europe has been less debated, possibly because with the only exception of the UK, in most European countries the changes in wage differentials have been rather modest (see Machin and Manning, 1994; Gosling, et al., 1996; and Machin, 1997 for the UK; and Machin and Van Reenen, 1998; and Koeninger et al., 2004 for international evidence). This relative stability of wage differentials in most European countries is often regarded as puzzling and explained by either the interactions of demand and supply, changing in a similar way such as to offset each other (OECD, 1996; Devroye and Freeman, 2002; Leuven et al. 2004; Nickell and Bell, 1996), or by the role played by labour market institutions (Blau and Kahn, 1996; Bertola et al. 2000; Haffner et al. 2001; Devroye and Freeman, 2002) or a combination of both (Acemoglu, 2002). A further element of this puzzle is due to the fact that most decomposition analyses of wage inequality reveal large and persistent rise in within-group earnings inequality, even controlling for changes in labour force composition, thus suggesting that much of the action has occurred within groups (i.e. education, cohort and gender), rather than between groups, and that a large portion of inequality still remains unexplained (Devroye and Freeman, 2002; Author, Katz and Kearney, 2005).

In this paper, we investigate the patterns of wage inequality, both between as well as within groups, in a number of European countries. In particular, while most of the existing contributions reviewed above have investigated the role played by market and institutional factors in determining differences across countries in the overall inequality, or in the structure of wage differentials, here we also focus on the effects of those factors on the conditional wage dispersion within each educational group. In fact, if the changes in relative supply and demand of education were a major explanatory factor for country differences in the distribution of earnings, the difference in the dispersion would decline as we consider 
inequality within educational groups. We show that a significant part of earnings inequality still remain unexplained within groups and try to account for the factors that can explain these differences.

So far there is no consensus about the magnitude of the effects of market forces versus institutions on wage inequality. One reason is lack of adequate comparable data. Studies adopting the methodology of Katz and Murphy (1982) use different measures of skills prices based on scarce internationally comparable data, mostly with few observations from each country (Blau and Khan, 1996). Most attempts to assess the impact of institutions, on the other hand, use overall measures of wage inequality such as the distance between the 90th and the $50^{\text {th }}$ percentile of the log wage distribution (Lucifora, 2000; Koeniger et al. 2004). We contribute to this literature along several dimensions. First, we model relative demand and supply of education to explain how changes in educational levels and labour market institutions account for the observed pattern of inequalities and allowing for imperfect substitutability of workers across skill groups. Second, in the empirical analysis, we use a panel of observations with detailed information on the distribution of wages for 12 European countries. In particular, we use measures of wage dispersion and skills prices that are estimated from large micro data sets (using quantile regression results) for each country, adding up to hundreds of thousands of observations of wages ${ }^{1}$. Third, we investigate the determinants of different conditional percentile log wage differences (Q9010, Q9050 and Q5010) within each educational level. In this way we are able to make a better assessment of the relative impact of markets and institutions on the wage structure, and in particular to investigate what dimensions and parts of the wage distribution are affected by the different types of institutions. In particular, in line with the literature on these issues, we consider the following labour market institutions: union density, coordination in collective bargaining, replacement ratio of unemployment benefits, and employment protection measures.

Furthermore, we analyse the relationship between the trend in conditional wage inequality within educational groups, which is particularly large and positive for tertiary education, and the boom in higher education. In particular, we use differences in the timing and strength of the expansion of tertiary education between countries to identify effects of expansion of the educational system on the quality of the skills of graduates as evaluated by employers in the labour market. If the expansion of the educational system leads to an erosion

\footnotetext{
${ }^{1}$ We thank the EDWIN partners for running the programs on their data sets, and providing us with a time series of data from each country. The data is supplemented by data estimated using the five waves of the European Community Household Panel (ECHP). See Peracchi (2002) and the data section and appendix for details.
} 
of skills among tertiary educated workers, we would expect increases in tertiary education to be associated with a widening of the conditional wage dispersion, in particular at the bottom of the wage distribution of tertiary educated workers. A hypothesis of over-education would lead to similar predictions: A drop in the bottom of the wage distribution for tertiary educated workers as the number of workers that have to take jobs below their qualifications increases. Also, an increasing mismatch between choices made with respect to the type of education and the occupational structure implied by demand could drive an increase in the conditional wage dispersion within educational levels as education expands (Dupuy and Borghans, 2003).

The paper is organised as follows. Section 2 gives an overview of the boom in education in Europe over the last decades and discusses the main factors that shape the wage distribution. In section 3, we present different measures of conditional wage inequality and section 4 describes the data used. Section 5 relates wage inequality to the supply of higher education as well as the institutional factors. Section 6 analyses the determinants of conditional wage dispersion. Section 7 concludes.

\section{Supply and Demand for Higher Education and Wage formation}

Over the last decades, tertiary education attainment levels more than doubled in most OECD countries. Countries characterised by a lower (initial) stock of high educated individuals experienced even higher growth in attainment levels, thus suggesting a catch-up phenomenon. The average share of the population with tertiary education in European countries increased from around 5 percent in 1960 to over 25 percent in 2003 (De la Fuente and Domenech, 2000; OECD, 2005). However, as shown in Table 1, these aggregate patterns conceal significant heterogeneity across countries. For example, the share of tertiary education in Austria, France, Italy and Greece, between 1960 and 2003, increased by 10 to 15 percentage points (from very low levels both in Austria and Italy); while, over the same period, in most other countries tertiary education grew by over 20 percentage points (over 25 percentage points in most Nordic countries, Denmark, Finland, Norway and Sweden).

Differences across countries also increased over time, as measured by the standard deviation of tertiary education attainment which almost tripled in the period considered. In the light of this rapid growth in the supply of tertiary education, various (and diverse) effects are likely to affect the functioning of the labour market and the structure of wages. 
Table 1 - Attainment in tertiary education: European countries

\begin{tabular}{|lccccccccccc|}
\hline & $\mathbf{1 9 6 0}$ & $\mathbf{1 9 6 5}$ & $\mathbf{1 9 7 0}$ & $\mathbf{1 9 7 5}$ & $\mathbf{1 9 8 0}$ & $\mathbf{1 9 8 5}$ & $\mathbf{1 9 9 0}$ & $\mathbf{1 9 9 5}$ & $\mathbf{2 0 0 3}$ & diff. 2003-1960 \\
\hline Austria & 4.1 & 4.5 & 4.9 & 6 & 7.4 & 9.2 & 11.2 & 12.4 & 14.5 & 10.4 \\
Belgium & 7.8 & 9.9 & 12.1 & 13.7 & 15.3 & 17.9 & 20.8 & 24.6 & 29 & 21.2 \\
Germany & 4.2 & 6.7 & 9.1 & 11.4 & 13.2 & 15.6 & 18.5 & 20.5 & 24 & 19.8 \\
Denmark & 7.1 & 9.9 & 12.8 & 14.8 & 16.8 & 18.3 & 19.3 & 20.8 & 31.9 & 24.8 \\
Spain & 3.1 & 3.5 & 4 & 5.4 & 6.9 & 8.2 & 9.5 & 12.5 & 25.2 & 22.1 \\
Finland & 6.9 & 8.5 & 10.2 & 12.6 & 15.1 & 17.6 & 20.2 & 23.6 & 33.3 & 26.4 \\
France & 9.4 & 10.4 & 11.8 & 13.7 & 16.4 & 19.2 & 21.9 & 22.5 & 23.4 & 14 \\
United Kingdom & 4.9 & 6.3 & 7.6 & 8.9 & 10 & 11.9 & 13.9 & 18.9 & 28 & 23.1 \\
Greece & 3.7 & 4.3 & 4.9 & 6.6 & 8.5 & 9.7 & 10.9 & 14 & 18.3 & 14.6 \\
Ireland & 4 & 4.4 & 5.4 & 6.5 & 7.7 & 10.6 & 13.9 & 18.3 & 26.3 & 22.3 \\
Italy (1) & 2 & 2.7 & 3.4 & 4.1 & 4.7 & 5.4 & 6.3 & 7.8 & 10.4 & 8.4 \\
Netherlands (1) & 3.3 & 4.6 & 6 & 8.2 & 10.7 & 13.2 & 15.7 & 19.4 & 24.4 & 21.1 \\
Norway & 4.2 & 5.5 & 6.7 & 8.7 & 11.1 & 13.6 & 15.7 & 19.7 & 31 & 26.8 \\
Sweden & 4.8 & 5.7 & 6.7 & 10.1 & 13.6 & 17.1 & 20.5 & 24 & 33.4 & 28.6 \\
\hline Average (unw.) & 5.0 & 6.2 & 7.5 & 9.3 & 11.2 & 13.4 & 15.6 & 18.5 & 25.2 & \\
Stand. Dev. & 2.1 & 2.5 & 3.1 & 3.5 & 3.9 & 4.4 & 4.8 & 5.0 & 6.9 & \\
\hline
\end{tabular}

Notes: (1) Year of reference 2002

Source: De la Fuente and Domenech (2001); OECD (1995, 2005)

In the framework of a simple supply-demand model, such an increase in the share of highly educated workers would, ceteris paribus, lower the (average) return to tertiary education and compress wage differentials between educational levels -- i.e. as the supply of skills shifts along the relative demand curve (Katz and Murphy, 1992; Bound and Johnson, 1992). The sustained productivity growth, driven by (skilled biased) technological change, is also likely to play a role as technical progress modifies factor shares in production by increasing the number of highly educated workers and thus raising the returns to education -i.e. as the relative demand curve for skills shifts outwards (Machin and Van Reenen, 1998; Acemoglu, 1998; 2002).In this context, skill premia are likely to depend on the differences between supply and demand, or as coined by Tinbergen (1952) on the "race between technology and education" (see also, Nickell and Bell, 1996; Leuven et al, 2000; Devroye and Freeman, 2002). Changes in the tertiary education wage premium appear to be partly explained by standard models emphasizing changes in the relative supply and relative demand for tertiary education, as well as by different roles of labour market institutions and changes in the institutional setting (Freeman, 1980; Freeman and Medoff, 1984; Blau and Kahn, 1996; 2000). These long run transformations have been accompanied also by major changes both in 
the allocation of work in the labour market and in the ways work is organised within firms (Osterman, 2000).

The effects on the distribution of wages, however, are likely to go beyond the changes in the returns to educational levels. Indeed, as the relative supply of more educated workers goes up, a reallocation of workers between different segments of the labour market is likely to occur, such that the skills distribution "within" different educational groups may also change. If education is mainly a reflection of innate skills, such that unobserved ability is an important determinant of wages, a rise in educational attainment will reduce ability at the lower end of the distribution for the more educated (simply by recruiting more students from the lower part of the skills distribution) and thus increase wage inequality within tertiary education (Leuven, et al., 2004). Also, wage dispersion within secondary education is likely to be affected, since the higher intake of student at the tertiary level, will lower average ability within secondary education and reduce the conditional dispersion of wages.

A similar effect "within" groups can be at work also on the demand side. On the one hand, a demand shift in favour of the more educated introduces a higher premium on skills for any given level of education and can increase within group inequality (Juhn et al, 1993). Empirical evidence on the returns to computer use and on the relevance of technical skills, seem to support the view that a considerable share of changing inequality might well occur within educational levels (Krueger, 1993; Murnane et al, 1995). On the other hand, under the pressure of (skill-biased) technical progress, both the skills structure of demand and the organisation of work are likely to change: requiring not only more educated workers but also more technical education vis-à-vis general education --. At the same time, if the structure of supply by "type" of education (technical versus general) only changes gradually, there will be increasing mismatch on the labour market with excess demand for high-skill technical jobs and misallocated workers with general skills. While the effect on the upper part of the conditional wage distribution is likely to increase dispersion, the impact on the lower part is more uncertain depending on the wage effects of mismatch (Dupuy and Borghans, 2003). Hence, the working of these different effects will produce a sort of "skills erosion" among higher educated workers, which will increase (conditional) wage dispersion within the more educated, while the net effect on the lower educated is likely to be indeterminate.

Finally, considering the relevance of institutional features both on the product and the labour markets in most European countries, the effects on overall wage dispersion are also expected to depend on labour market institutions. As previously discussed, among the institutional features that traditionally in the literature are considered important for wage 
formation are: unions and bargaining institutions, wage regulation and welfare benefits, and labour market policies. A common finding of the studies that have investigated the effects of institutions on wage dispersion is that the interactions between supply, demand and institutions can take several routes altering both the between as well as the within structure of wages (Brunello et al., 2000; Bertola, et al., 2002; Acemoglu 2002; Card and Lemieux, 2001; Card and DiNardo, 2002). We review them in turn. One route is by raising the pay levels of those workers covered by collective agreements relative to non-covered workers (Freeman and Medoff, 1984). In this way, wage differences among otherwise similar workers may increase wage dispersion within groups ${ }^{2}$. Alternatively, "standard rate" wage policies in collective agreements, by fixing both the number of job categories in which workers are placed and the rate of pay for each job, seek to limit the ability of employers to remunerate workers differently (i.e. performance related pay, individual wage premia) and thus reduce overall wage dispersion. Also, regarding the union as a political organisation whose consensus depends on median preferences, when the median wage is less then the mean wage a majority of workers will support a wage policy favouring the lower paid, thus further reducing dispersion (Freeman, 1980; Hirsch and Addison, 1986). Hence in this respect, the overall impact of unionisation on pay dispersion (both between and within) is a priori ambiguous and likely to depend on the prevailing effect.

One further route, is related to bargaining coordination and centralization of bargaining which, by setting common standards in the wage setting process, are expected to reduce dispersion across the board (Moene and Wallerstein, 1997; Wallerstein, 1999; OECD, 2004).

Employment protection policies are often associated with a more compressed wage structure. As argued by Bertola and Rogerson (1997), quantitative firing restrictions could hardly be binding if wages were completely unrestrained and employers could reduce them so as to make stable employment profitable ${ }^{3}$; hence, employment protection measures and wage regulations (such as minimum wages) are often combined, limiting the freedom offered to employers in setting wages and thus reinforcing their impact on wage dispersion. Indeed, the presence of a statutory minimum wage by setting an explicit threshold for the lowest wage

\footnotetext{
${ }^{2}$ The impact on wage inequality will effectively depend on the position of the workers affected by the union mark-up within the overall wage distribution. Inequality will be reduced if union workers have below-average pay levels, and conversely increased if union workers have above-average pay levels.

3 The combination of wage compression and employment protection measures may reflect "..a desire by organized labor to enforce monopolistic wage-setting practices by preventing underbidding by the unemployed." and be a powerful source of insider power (Bertola, et al., 2000).
} 
rate paid tends to reduce wage dispersion. Also, unemployment benefits, by providing an outside option to workers, set a floor to wages and lead to wage compression. Because of their regressive nature, such measures are likely to have a stronger effect at the bottom of the wage distribution rather than at the top (Nickell and Layard, 1999; Lucifora, 2000).

Identifying the effects of institutions on wage dispersion is not an easy task, since both data requirements as well as model specification are quite demanding. A few caveats are worth discussing. First, it is important to simultaneously model the effects of demand, supply and institutions on wage formation. For example, as shown by Gottschalk and Smeeding (1997) and Gottschalk and Joyce (1998), when analysing the effects of centralisation in wage setting on wage inequality it is important to control for supply effect, since countries where wage setting is more centralised also experienced larger shifts in the relative supply of high skilled labour. In this context, failing to control for supply effects may attribute the effect on wage inequality to centralisation of bargaining. We control for supply shocks as well as for union density and coordination to be able to disentangle the effects. Second, the effects of institutions in regulating pay might change over time -- due to market de-regulation, erosion of workers' guarantees or simply de-unionisation and decentralisation of collective bargaining - such that time varying information on institutions is necessary (Nickell et al. 2004). Finally, dealing with the potential endogeneity affecting the interactions between supply, demand, wage formation and institutions is important. While, there is no satisfactory way of dealing with endogeneity of institutions - which we assume as predetermined --, we carefully address the issue of (relative) wage determination and market interactions using an instrumental variable estimator.

\section{Empirical Method and Measures of Wage Dispersion}

In this section we first provide a model of supply, demand and wage determination that we formalise into a simple system of empirical equations to be estimated, followed by a brief account of how we measure wage dispersion along several dimensions.

\subsection{Technology and labour demand}

Consider the following simple CES-production function.

$$
y=\left\{\theta_{p} P^{\rho}+\theta_{S} S^{\rho}+\theta_{T} T^{\rho}\right\}^{\frac{1}{\rho}}
$$


where $\mathrm{P}$ is the number of workers with primary education, measured in efficiency units, $\mathrm{S}$ is the number of workers with secondary education and $\mathrm{T}$ is the number of workers with tertiary education, measured in efficiency units:

$$
\begin{aligned}
& P=\sum_{i} \alpha_{i} P_{i} \\
& S=\sum_{i} \beta_{i} S_{i} \\
& T=\sum_{i} \gamma_{i} T_{i}
\end{aligned}
$$

where $P_{i}$ measures the number of workers with primary education of skill group $i$ of relative efficency $\alpha_{\mathrm{i}} . \mathrm{S}$ and T are defined accordingly. We normalize the efficiency units such that the parameters $\theta_{\mathrm{e}}, \mathrm{e}=\mathrm{P}, \mathrm{S}, \mathrm{T}$, measure the distribution parameter of the median worker within each educational group, i.e. we set $\alpha_{50}=\beta_{50}=\gamma_{50}=1$, where subscript 50 refers to the skill group of the median worker. The term $\left(\theta_{\mathrm{T}} / \theta_{\mathrm{P}}\right)$ can be interpreted as the standard measure of skill biased technological change (i.e. Katz and Murphy, 1992). The efficiency units $\alpha_{i}, \beta_{i}$, and $\gamma_{i}$ thus measure efficiency relative to the median worker within each educational group.

From (1) and (2) we note that workers within each educational group are assumed to be perfect substitutes, regardless of efficiency level, while there is imperfect substitution across educational groups. The elasticity of substitution between workers of different educational levels is given by $\sigma=1 /(1-\rho)$, where $-\infty<\rho<1$. Demand for workers of skill group $i$ with tertiary education is given by the standard first order condition equalizing the wage with marginal product:

$$
w_{T, i}=y^{\frac{1}{\sigma}} \theta_{T} v_{i} T^{\frac{-1}{\sigma}}
$$

Demand for $\mathrm{P}$ and $\mathrm{S}$ workers is defined accordingly. In the analysis below, we use two measures of relative wages extensively. These are the between and the within group relative wages, defined by the ratios of different values of (3). We have:

$$
\begin{aligned}
& \omega=\frac{w_{T, 50}}{w_{P, 50}}=\frac{\theta_{T}}{\theta_{P}}\left[\frac{T}{P}\right]^{\frac{-1}{\sigma}} \\
& \omega_{i, j}=\frac{w_{T, i}}{w_{T, j}}=\frac{\gamma_{i}}{\gamma_{j}}
\end{aligned}
$$

These two relative wages have clear empirical counterparts in terms of standard measures obtained from quantile wage regressions: (4a) can be measured by the wage premium for the 
median worker of obtaining tertiary education relative to primary education, or the median return to tertiary education, while (4b) can be measured by the inter-quantile range (where $i$ is the $90^{\text {th }}$ percentile and $j$ is the $10^{\text {th }}$ percentile) of expected wages conditional on tertiary education. With the normalization chosen in this paper, we measure this effect directly from the median return to education. Furthermore, the assumption of perfect substitution within educational groups (note that we also condition on experience and gender in the empirical analysis below) allows us to identify the relative efficiency units from the expected wage of each decile of the conditional wage distribution.

\subsection{A simple model of wage determination}

Consider the following simple model of wage determination of the wage premium associated with higher education. Define $\omega=W_{T 50} / W_{P 50}$ as the relative wage for the median worker of tertiary education to primary education. Relative demand is then given from (4a) by:

$$
\left(\frac{T}{P}\right)^{D}=D \omega^{-\sigma}
$$

where $\mathrm{D}$ is the relative demand shifter $D=\left(\theta_{T} / \theta_{P}\right)^{-\sigma}$ according to (4a). Relative supply is assumed to be given by:

$$
\left(\frac{T}{P}\right)^{S}=S \omega^{\eta}
$$

where $\eta$ is the elasticity of relative supply with respect to the wage premium associated with tertiary education in the labour market and $\mathrm{S}$ is the relative supply shifter.

The market clearing relative wage, $\omega^{*}$, is given by the relative wage that equates relative demand and relative supply:

$$
\omega^{*}=\left(\frac{S}{D}\right)^{-\frac{1}{\sigma+\eta}}
$$

Wage determination is modelled as follows:

$$
\omega=B^{(1-m)}\left(\omega^{*}\right)^{m}
$$

where $B$ is a measure of the relative bargaining power of the employees with tertiary education relative to the employees with primary education only. We use $m \in(0,1]$ to measure of the impact of market forces on relative wages, relative to institutional factors 
affecting bargaining power. Equations (5), (6) and (8) contain three endogenous variables: relative demand, relative supply and relative wages. Taking logs we obtain the following equations to be estimated:

$$
\begin{aligned}
& \log \left(T^{D} / P^{D}\right)=d-\sigma \log (\omega)+u \\
& \log \left(T^{s} / P^{s}\right)=s+\eta \log (\omega)+v \\
& \log (\omega)=(1-m) b-(m /(\sigma+\eta))(s-d)+w
\end{aligned}
$$

where $d, s$ and $b$ stands for the $\operatorname{logs}$ and $u, v$ and $w$ are disturbance terms. A similar set of equations is obtained for the market for secondary education ( $S / P$ etc.). Denote these equations (9'), (10') and (11'), defined accordingly. According to (1) the parameter $\sigma$ should be equal across all equations - a testable assumption - while the other parameters may differ between the two educational groups.

In (9)-(11), $d, s$ and $b$ contain exogenous variables. We note that (11) contains exogenous variables only, and that identification of $m$ is possible, given a value of the net supply shifter $(s-d)$ as well as consistent estimates of $\sigma$ and $\eta$. A convenient way of estimating the system of equations is, thus, to estimate (9) and (10) (as well as (9') and (10')) using 2SLS, instrumenting the wage variable, using as instruments the vector of exogenous variables contained in $\mathrm{b}$ as well as the exogenous variables in the supply equation (the elements of $s$ not included in $d$ ) when estimating demand and the exogenous variables in the demand equation (the elements of $d$ not included in $s$ ) when estimating the supply equation. Next, (11) (and (11')) can be estimated by standard OLS, using the estimated values of the demand and supply shifters as exogenous variables.

\subsection{Within group wage dispersion}

The market clearing within group relative wage is given by $(4 b)$. Note that with the specification of the production function we have chosen, the relative productivity of workers within each educational group is assumed to be constant and independent of the scale of production or, more specifically, independent of the scale of input of education. Thus, changes in relative productivity arise only from changes in the distribution of skills supplied to firms (or changes in the distribution of skills among the unemployed). We stick to this assumption here, but allow for a more flexible interpretation of the results in the concluding discussion.

The hypothesis of skills erosion can be specified as follows: 


$$
\gamma_{j}=\gamma_{j}^{c} T^{-\kappa_{j}}
$$

where $\gamma_{j}^{c}$ represent scale independent factors of relative productivity of each percentile of the productivity distribution, $\mathrm{T}$ is the size of tertiary education and $\kappa_{\mathrm{j}}$ is a measure of the skills erosion associated with percentile $j$ as tertiary education expands.

The relative wage that equates the relative demand and supply of different deciles of the productivity distribution within each educational group is thus given by:

$$
\left(\omega_{i, j}\right)^{*}=\left(\frac{\gamma_{i}^{c}}{\gamma^{c}{ }_{j}}\right) T^{\left(\kappa_{j}-\kappa_{i}\right)}
$$

Again, we use a wage formation mechanism that allows for departures from the market clearing one:

$$
\omega_{i, j}=B_{i, j}{ }^{(1-m)}\left(\omega_{i, j}{ }^{*}\right)^{m}=B_{i, j}{ }^{(1-m)}\left(\frac{\gamma_{i}^{c}}{\gamma^{c}{ }_{j}}\right)^{m} T^{m\left(\kappa_{j}-\kappa_{i}\right)}
$$

implying that relative wages depend on relative bargaining power between the different percentiles within tertiary education, scale invariant factors related to relative productivity of the different percentiles (such as technological or organisational change) and to the scale of tertiary education. Similar expressions may be derived for secondary and primary education as well. In our empirical analysis, we estimate variants of (15) above, for Q9010, Q9050 and Q5010 in order to test the skills-erosion hypothesis. Since it is unclear from this specification how $T$ is determined (exogenous or endogenous in relation to within educational group relative wages), we try both specifications where $T$ is assumed to be endogenous and where $T$ is assumed to be exogenous.

\subsection{Measures of wage dispersion}

We measure the between group wage dispersion by the estimated return to education from median regressions of log hourly wage on our primary data sets. The median regression models, which are estimated for each country and year where we have observations (see the next section for details and definitions), controls for age, age square, and dummies for gender, manufacturing and private sector. The coefficient thus measures the wage premium associated with the level of education. We estimate both the wage premium associated with tertiary 
education and the wage premium associated with secondary education relative to primary education.

The inter-quantile range ${ }^{4}$ is used to measure within group wage dispersion. For each year of each country in our primary data sets, we have estimated a quantile regression model of log hourly wage, controlling for educational level, gender, age, age square, private sector and manufacturing. We then predict the wage, conditional on educational level, gender, age, private sector and manufacturing for the $9^{\text {th }}$ decile as well as for the $1^{\text {st }}$ decile. We chose a male, 40 years of age, working private sector manufacturing as our reference person within each educational group. Within group wage dispersion is defined by the inter-quantile range for this reference person as,

$Q 9010=X^{\prime}[\beta(90)-\beta(10)]$

where $X$ is the vector containing the values of the covariates for the reference person, and $[\beta(90)-\beta(10)]$ is the vector of the difference in the estimated coefficients (including the constant terms) for the $9^{\text {th }}$ and the $1^{\text {st }}$ decile of the conditional wage distribution respectively. Q9010 is calculated for each educational group in each country per year of observation. Intuitively $\mathrm{Q}_{\mathrm{ij}}$ measures the $\log$ of the relative wage between the upper part of the wage distribution (the $i$-th percentile) and the lower part of the wage distribution (the $j$-th percentile), within each educational group.

\section{Data}

Wage dispersion is measured from the results of 117 year and data-set specific quantile regressions. Our primary data sets, on which the separate quantile regressions are estimated, consist of more than 1.4 million observations from 16 data sets covering 12 European countries. We have national data sets from 8 of the 9 countries that participated in the EDWIN project. These are Finland, France, Germany, Greece, Italy, Norway, Sweden and the United Kingdom. The years of observation range from 1973 to 2003. The name of the data sets, years and the total number of observations from each data set are reported in the data appendix. We label these data the EDWIN sample. We also use micro data from the European Community Household Panel (ECHP) -- from 1994 to 2000, for Austria, Belgium, Denmark, Finland,

\footnotetext{
${ }^{4}$ See Buchinsky (1994) for a discussion of the usefulness of this measure of within group wage dispersion.
} 
France, Greece, Italy, and Spain -- in order to expand the data set with respect to the number of countries covered, as well as years for some of the countries (Peracchi, 2002) ${ }^{5}$.

In each of the data sets included in the analysis, the sample consists of all employees aged between 18 and 64 with employment in the non-agricultural sectors of the economy, working between 15 and 84 hours per week. The definition of earnings is "gross hourly earnings", except for Greece and Italy for which only net hourly earnings (after income taxes and social security contributions) were available In all the analyses below we include country $x$ dataset dummies to account for country specific effects as well as fixed idiosyncrasies related to each individual data set. We also include an ECHP-specific time trend in all regressions in order to adjust for potential differences in survey design over the years from ECHP and the national data sets.

The secondary data set consists of 117 observations of estimated wage premia drawn from quantile regressions separately fitted for each year and primary data set. The wage premia are estimated conditional on gender, a manufacturing dummy, a private sector dummy, and a Mincer's experience term and its square. In order to measure "between" educational wage differentials, we retrieved the estimated coefficient, in a median regression model, on tertiary and secondary education relative to primary education. Conversely, "within" wage dispersion is measured by the conditional inter-quantile range, retrieving estimated coefficients at the $90^{\text {th }}$ and the $10^{\text {th }}$ percentile from quantile regressions and computing, separately for each educational group, the inter-quantile range for a male, private sector manufacturing employee of 40 years of age.

We have merged, into the secondary data set, additional data on both supply and demand for the three groups of education. Population shares of tertiary, secondary and primary education are obtained from the various years of Education at a Glance (with some interpolation of missing intermediate years $)^{6}$. The population shares of tertiary education is supplemented with data from De la Fuente (2004), while the population shares of secondary education is supplemented with data from our primary data sets as well as from national Labour force surveys. Employment rates for the different educational groups are obtained from national Labour force surveys and the primary data sets.

\footnotetext{
${ }^{5}$ We did not include ECHP data for Germany and the UK because the definition of educational groups resulted to be quite different than in the national data sets, we also did not include Sweden as information on wages was lacking. See Eurostat $(1996 ; 2000)$ for technical details on methodology and implementation for ECHP data.

${ }^{6}$ See Barro and Lee $(1996,2000)$ for a discussion on international data on educational attainment. Also De la Fuente and Domenech (2000) discuss human capital data quality.
} 
Institutional variables include union density and coordination in bargaining, both which are obtained from the Golden, Lange and Wallerstein (2002) data set, supplemented with data from OECD. The coordination variable is normalised to be between 0 and 10 , where 0 is completely decentralised wage setting and 10 represents complete national negotiations over wages $^{7}$. Variables on employment protection and the replacement ratio for unemployed are obtained from the Blanchard and Wolfers (2000) data set (see appendix for details). The latter are also normalised between 0 and 10, where 0 is no protection, and the lowest level of unemployment benefits, while 10 represents the highest level in both cases. We also use information on public expenditure on tertiary education (obtained from OECD data). We lack institutional variables for Greece. The values for these countries are set to zero in our data, and all analyses that include institutional variables also include a separate dummy and separate time trend for both Greece in order to capture the potential effects of these variables. The Data appendix provides details on all variables used in the analysis.

\section{Results}

Is there a European trend in the conditional between- and within educational group wage dispersion for tertiary and secondary education? In figure 5.1. we report the estimated time dummies for the 20 years from 1984 to 2003 of the different wage dispersion measures, obtained from simple WLS regression (weighted with population size) of our measures of wage dispersion including a time dummy and a country $x$ dataset dummy ${ }^{8}$. The reference year for all effects is 1983, so the coefficient may be interpreted as the European population weighted average log point growth in each measure since 1983. Consider tertiary education first, as illustrated in figure 5.1.(a). The crosses shows the time dummies of the wage premium related to tertiary education relative to primary education. A fitted trend line is also displayed, however, trend terms are not statistically significantly different from zero.

The inter-quantile range $(\log 9010)$, on the other hand, displays a considerable growth over time. From 1983 to 2003 the inter quantile range has increased by $22 \log$ points, according to the fitted line displayed in the figure. (a second order polynomial). This trend is statistically significant, and certainly economically significant.

\footnotetext{
${ }^{7}$ See Visser (2000) for a discussion on combined indicators of union centralisation and coordination.

${ }^{8}$ The models also included a separate time trend for ECHP data.
} 


\section{Figure 5.1. Trends in Wage Dispersion Between and Within Educational Groups.}

\section{(a) Tertiary education}

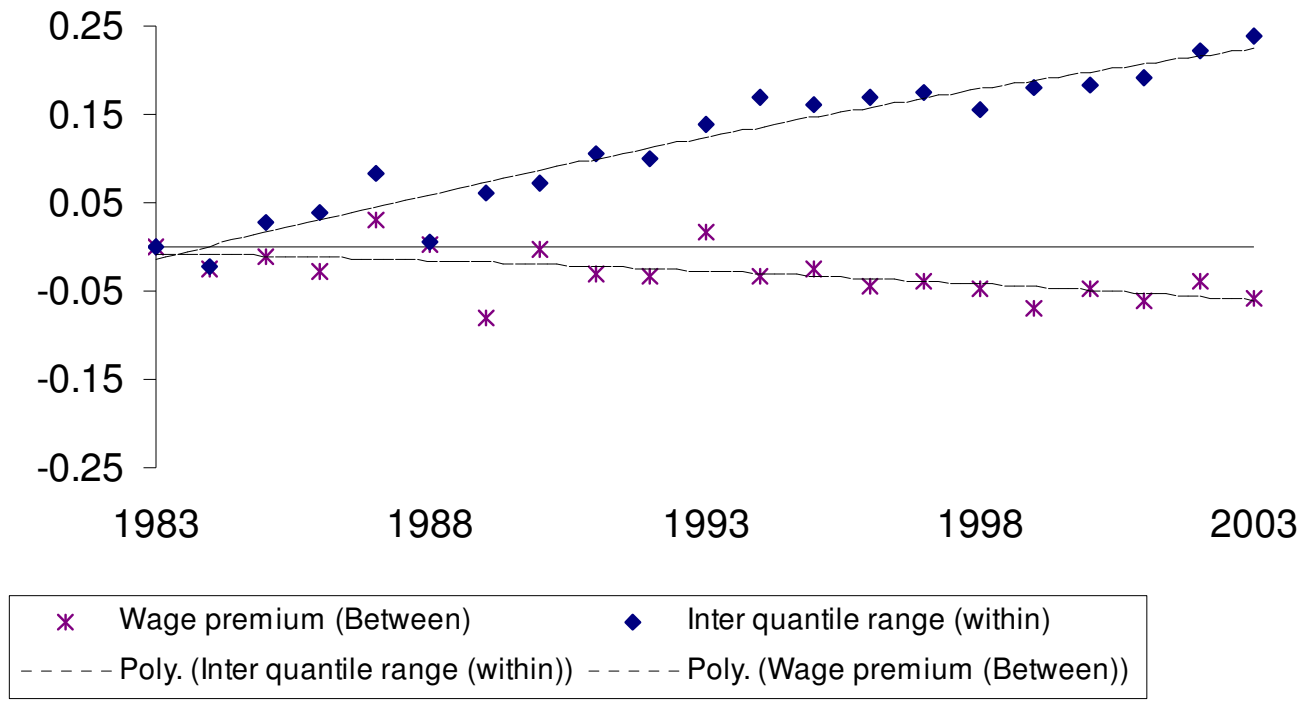

\section{b) Secondary education}

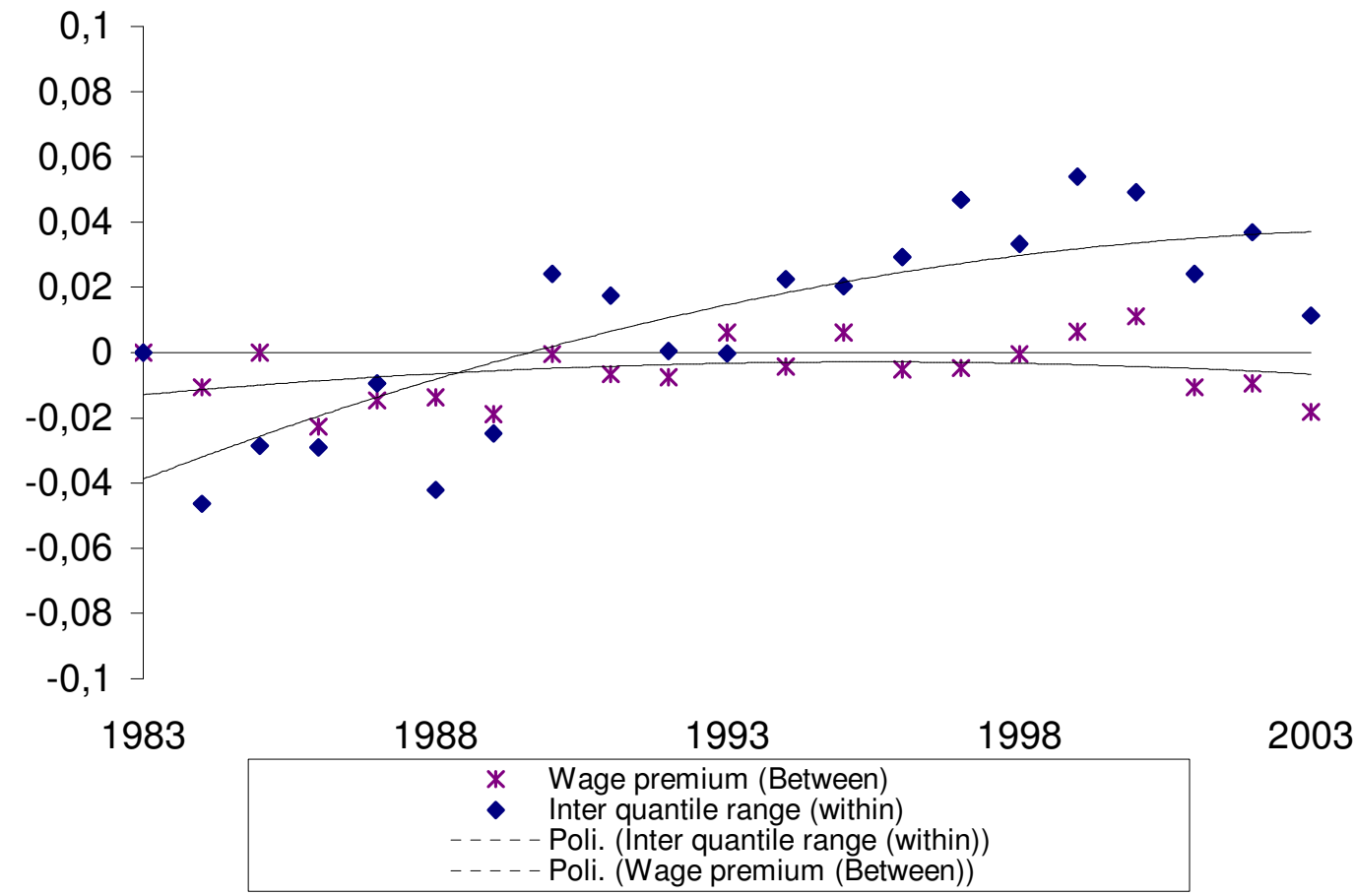

Source: Time dummies from simple WLS regressions (population weighted) of the two measures of wage dispersion on countryxdataset dummies, year dummies and a separate time trend for echp data. The fitted lines are second order polynomial representations of the data points. 
Figure 5.1.(b) provides the same picture for secondary education. Also here, the between group difference (the wage premium associated with secondary education relative to primary) shows no significant trend, while the fitted second order polynomial to the time dummies associated with the inter quantile range suggest a growth in within group inequality of $0.08 \log$ points, within secondary education.

We first analyse the wage premium associated with tertiary and secondary education relative to primary education. According to the discussion in section 3 this basically amounts to estimating the elasticity of substitution between the two groups as well as the relative wage equation. We then turn to within-group inequality in the subsequent section.

\subsection{The Market for Higher Education}

In this section we analyse relative demand, relative supply and relative wages of employees with different levels of education. Our focus is on employment rates, labour force participation rates and wage rates "between" educational groups. As measure of the relative wage premium associated with education level, we use the estimated relative wage of the median worker within each educational group ${ }^{9}$. The three main questions we address in this section are: (i) What is the elasticity of substitution between educational groups? (ii) Has demand kept pace with the boom in supply? and (iii) How do relative wages react to changes in market forces (demand and supply) and/or institutions (labour market policies and bargaining institutions)?

The pattern of relative employment and relative wage for tertiary (panel (a)) and secondary (panel (b)) education -- estimated on the EDWIN and ECHP data -- is displayed in $\operatorname{logs}$ in Figure 5.2. We find a considerable growth in relative employment of tertiary education in all countries considered ${ }^{10}$. Relative wages, however, display a quite flat development, falling rather than rising. In the empirical analysis below, we restrict the sample to the time periods where we have observations on both relative employment and relative wages (117 data points). Note, however, that all of our preferred models below include a "country times dataset" dummy as well as a specific trend variable for the ECHP data ${ }^{11}$. This means that we are identifying our effects from differences in development over time between countries.

\footnotetext{
${ }^{9}$ More precisely, we utilize the results from quantile regressions for the median of the conditional wage distribution within each educational group. See section 4 for details.

${ }^{10}$ Relative demand is measured by (the log of ) the employment share of tertiary (or secondary) education divided by the employment share of primary education.

${ }^{11}$ We also present results with and without the ECHP data sets included in the analyses to verify the robustness of our results.
} 
Figure 5.2. Relative employment and relative wages for tertiary over primary education

Panel (a) - in logarithms. Left axis: relative employment, right axis: relative wage

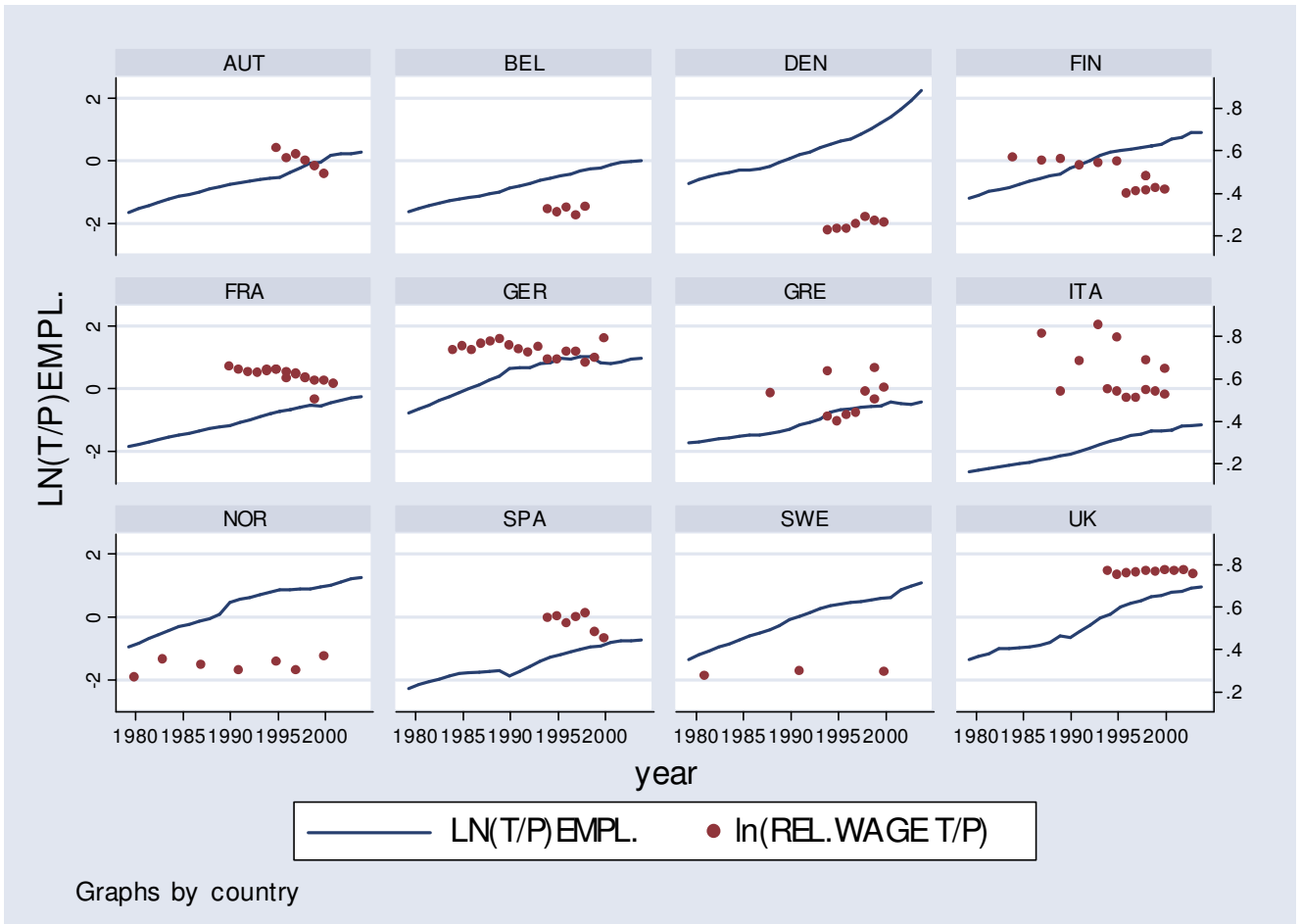

Panel (b) - in logarithms

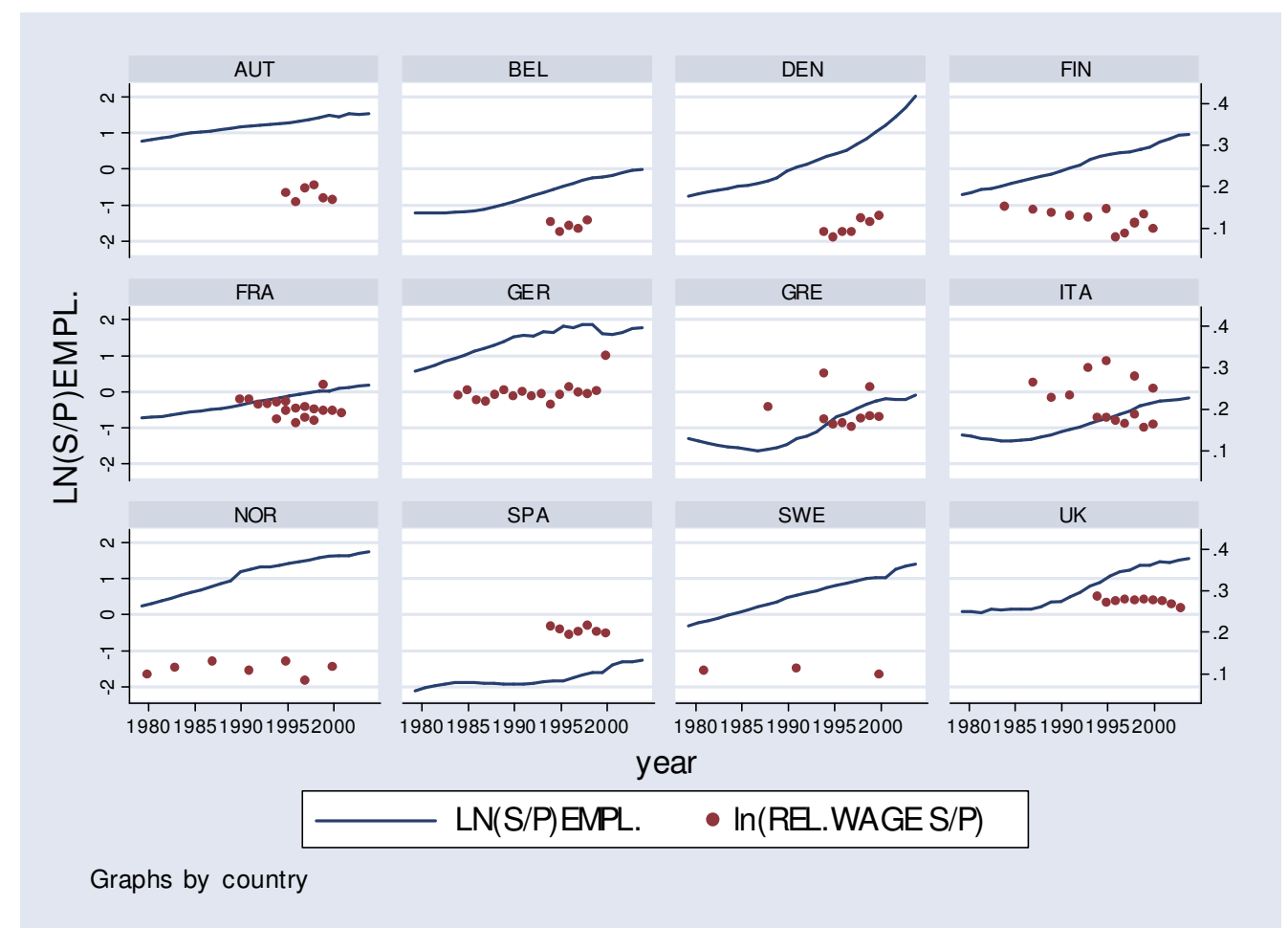


There are two common objections to the use of cross-national data for this type of empirical analysis. The first is that countries are very heterogeneous, both in terms of variable definitions and data quality and in terms of omitted variables. The second is that identification may depend heavily on the inclusion of a few data points.

Since we use a panel of data sets, we are able to use model specifications including fixed time and country effects, and thus effectively purge out any observed or unobserved time invariant difference between countries (and data sets). In this way, we mitigate the consequences of the first objection to a considerable extent. In the empirical analysis below, we also report sensitivity analyses of our results restricting the analysis to either of the data set and to different sub-samples of countries (i.e. excluding sets of countries).

Table 5.1 reports results from the estimation of the demand for tertiary and secondary education relative to primary education (equation (9) above).

Table 5.1. Demand Equations. Seemingly unrelated regression models Relative wages instrumented

\begin{tabular}{|c|c|c|c|c|}
\hline & $\begin{array}{l}\text { Model } 1 \\
\text { SUR }\end{array}$ & $\begin{array}{l}\text { Model } 2 \\
\text { SUR }\end{array}$ & $\begin{array}{l}\text { Model } 3 \\
\text { SUR }\end{array}$ & $\begin{array}{c}\text { Model } 4 \\
\text { IV }\end{array}$ \\
\hline \multicolumn{5}{|l|}{ Dep.var: In(Teriary/Primary) Employment } \\
\hline Relative Wage (Tertiary/Primary) & $\begin{array}{l}-2.1045^{\star} \\
(0.5117)\end{array}$ & $\begin{array}{l}-2.3298^{*} \\
(0.5515)\end{array}$ & $\begin{array}{l}-2.5752^{*} \\
(0.7492)\end{array}$ & $\begin{array}{r}-2.7926 z \\
(1.4546)\end{array}$ \\
\hline Linear trend & & & & $\begin{array}{r}0.0913^{*} \\
(0.0324)\end{array}$ \\
\hline F-test, instruments & 1.54 & 1.54 & 4.35 & 52.92 \\
\hline R-square & 0.9928 & 0.9928 & 0.9934 & 0.1803 \\
\hline \multicolumn{5}{|c|}{ Dep.var: In(Secondary/Primary) Employment } \\
\hline Relative Wage (Secondary/Primary) & $\begin{array}{l}-2.1045^{\star} \\
(0.5117)\end{array}$ & $\begin{array}{l}-1.6412^{*} \\
(0.6748)\end{array}$ & $\begin{array}{l}-2.5752^{*} \\
(0.7998)\end{array}$ & $\begin{array}{r}-7.0025 \\
(4.1031)\end{array}$ \\
\hline Linear trend & & & & $\begin{array}{r}0.0836^{*} \\
(0.0320)\end{array}$ \\
\hline F-test, instruments & 3.13 & 3.13 & 3.89 & 57.25 \\
\hline R-square & 0.9947 & 0.9944 & 0.9949 & 0.1541 \\
\hline Countryxdataset dummies & yes & yes & yes & no \\
\hline Year dummies & yes & yes & yes & no \\
\hline $\begin{array}{l}\text { Test of equal relative wage effect } \\
\text { p-value }\end{array}$ & & 0.2802 & & \\
\hline Cross equations correlation of residuals & 0.7184 & 0.7130 & 0.7159 & \\
\hline Number of Countries & 12 & 12 & 12 & 12 \\
\hline CountryxDatasets & 16 & 16 & 16 & 16 \\
\hline Observations & 117 & 117 & 117 & 117 \\
\hline
\end{tabular}

Note: $\left(^{*}\right)$ statistically significant at the 5 percent level. The models also include a time trend for ECHP data, a fixed effect and country specific time trend for Greece (for which no complete information on bargaining institutions is available). Relative wages are instrumented. The instruments are: In model 1,2, and 4: The bargaining institutions (union density and coordination in bargaining), the two policy measures (employment protection index and unemployment replacement ratio), as well as the set of supply shifters (lagged (t-3) population shares and the log of public expenditure on higher education). In model 3 the instruments are coordination in bargaining and lagged population share only. The ratio of $\sigma / \wedge \sigma$ is 1.38 and 1.06 for tertiary and secondary education in model 1. 
We instrument relative wages using the set of bargaining institutions (union density and coordination in bargaining ${ }^{12}$ ), the two policy measures (employment protection index and unemployment replacement ratio), as well as the set of supply shifters (lagged ( $t-3)$ population shares and the log of public expenditure on higher education). The demand shifter is represented by "country times dataset" and year dummies in the equation.

Model 1 reports our preferred equation. This model includes the full set of exogenous variables in the model (not included in the demand equation) as instruments. The estimated ${ }^{13}$ elasticity of substitution is 2.1. This estimate is higher than the preferred estimate of 1.4 for US college versus non-college workers reported by Katz and Autor (1999) and the estimated elasticity of substitution between tertiary and non-tertiary education of 1.3 reported by Barth and Røed (1999) for 15 European countries, but almost the same as the estimated elasticity of substitution between high school and college graduates reported by Card and Lemieux (2001). In model 2, we test the assumption of equal elasticity of substitution across the two educational groups, which cannot be rejected by the data. We also report from a specification with fewer instruments, since the F-value of the full set in the first stage is low. In models 13 , the R-square is very high. This basically reflects that most of the variation in relative employment rates are accounted for by country and time dummies. The estimate of the elasticity of substitution is thus based on differences in within country variation relative to the overall European development over time. For completeness, we report in model 4 from an IV regression of a parsimonious specification without country $x$ dataset fixed effects, and where the year dummies are replaced by a linear trend (in both first and second stage of the model). In this case, identification is provided by variations across as well as within countries, in the exogenous variables. We obtain a very similar estimate of the elasticity of substitution for tertiary education, and a much larger but very imprecise estimate for secondary education.

In order to check the robustness of our results, in Table 5.2 we present a series of coefficients estimated on sub-samples of the data sets. We use the specification of model 1 of Table 5.1. The first two lines check whether the results are robust to the use of different types of data sets, EDWIN versus ECHP. The estimated coefficients are within a reasonable range of the corresponding coefficients reported in Table 5.1. The next three lines report results that

\footnotetext{
${ }^{12}$ We do not have complete information on bargaining institutions for Greece. Hence, a fixed country effect as well as a country specific trend is included in all models to pick up underlying differences and changes in these variables.

${ }^{13}$ The correction terms of the standard errors are 2.09 and 1.26 for tertiary and secondary education respectively, in order to account for the fact that relative wage is instrumented (see note to model 1). The reported coefficients are significant at a 5 percent level taking this correction into account.
} 
exclude, group by group, the Nordic countries, the Southern countries and the smaller countries form the sample. The estimated results vary somewhat between the samples, from 1.4 to 4.8. The estimated elasticity of substitution is larger when estimated without the use of the smaller countries, in particular when excluding the Nordic countries, but is otherwise similar to the results reported in Table 5.1. Since there are only few and scattered data points from the Nordic countries, separate estimation of the model on these countries only is not feasible. Estimating the model on the small countries only, excluding France, Germany, Spain, Italy and the UK gives an estimated elasticity of substitution of 1.37 with a standard error of 0.85 , which is (statistically) significantly smaller than the one estimated for the large countries. However, if we restrict the specification to equal year effects across the subsamples, the difference in the estimates between small and large countries (not reported) gets smaller and is no longer statistically significant. We thus conclude that, given the number of observations and distribution of data points, the pooled model is preferable.

Table 5.2. Demand elasticity estimated on different sub-samples

IV-SUR models as in model 1 of Table 5.1

\begin{tabular}{lcr} 
Sub-sample: & $\begin{array}{r}\text { Coefficient } \\
\text { Std.error }\end{array}$ & $\begin{array}{r}\text { Number of } \\
\text { countries }\end{array}$ \\
\hline Observations
\end{tabular}

\subsection{Relative Supply of Education}

Consider next the supply equation. Relative supply is measured by the (log of) the relative share of the labour force with tertiary education relative to the share of the labour force with primary education. As explanatory variables, we have used the (logs of) the 
population shares three years before (tertiary education in population over primary education in population) as well as the log of public expenditures on tertiary education per capita. Therefore, the level of tertiary education in the labour force is explained by the level of tertiary education in the population three years before, the level of public expenditures on education as well as the relative wages.

Table 5.3. Supply equations (IV - regressions)

Dependent variables: $\ln$ (Tertiary/Primary), $\ln$ (Secondary/Primary) in Labour Force

\begin{tabular}{lccccccr} 
& \multicolumn{3}{c}{ Tertiary education } & \multicolumn{3}{c}{ Secondary education } \\
\hline & IV & IV & IV & IV & IV & IV \\
& (a) & (b) & (c) & (a) & (b) & (c) \\
\hline $\begin{array}{l}\text { Relative wage } \\
\text { (Tertiary/Primary) }\end{array}$ & $1.3588^{*}$ & $4.0773^{*}$ & $1.8558 z$ & & & \\
& 0.6823 & 1.2360 & 1.0457 & & & \\
Relative wage & & & & & & \\
(Secondary/Primary) & & & & & 2.1529 & 3.4764 & $8.3152^{*}$ \\
& & & & 1.7202 & 3.2772 & 3.9562 \\
LN(Public Expenditure) & 0.1401 & 0.1309 & $0.7170^{*}$ & 0.1530 & $0.1760^{*}$ & $1.6009^{*}$ \\
& 0.0991 & 0.1200 & 0.2816 & 0.0791 & 0.0834 & 0.6450 \\
Population share (t-3) & $1.3353^{*}$ & $1.4313^{*}$ & $0.9460^{*}$ & $0.9048^{*}$ & $0.8927^{*}$ & 0.1075 \\
& 0.0797 & 0.1347 & 0.2112 & 0.1020 & 0.1013 & 0.3812 \\
F-value, instruments & 1.22 & 5.16 & 49.57 & 1.53 & 7.36 & 50.94 \\
Countryxdataset dummies & Yes & Yes & No & Yes & Yes & No \\
& & & & & & &
\end{tabular}

Note: Note: $\left({ }^{*}\right)$ statistically significant at the 5 percent level. The models also include fixed countryxdataset effects and a specific time trend for ECHP data, and a fixed effect and country specific time trend for Greece, Relative wages are instrumented using the variables not included in the supply equation as instruments. The instruments in models IV (a) are: Union density, Bargaining coordination, Employment protection, Replacement ratio and year dummies. In models IV (b) the instruments are Bargaining coordination and a secon order polynomial in time. In models IV (c) there are no countryxdataset fixed effects.

In Table 5.3 (IV (a)) we find that there is a strong positive correlation between the supply of tertiary education and the lagged population share. This is merely a consequence of the fact that the educational attainment of the labour force is, to a large extent, predetermined by education obtained many years ago. Public expenditure has a statistically insignificant positive association with education. We find a positive effect of relative wages in all specifications, statistically significant for tertiary education only. Because the specification with time dummies and all other exogenous variables not in the supply equation as instruments have a low F-value for the instruments in the first step, we also report specifications (IV b) with a more parsimonious set of instruments for relative wages, namely bargaining coordination and a second order polynomial in time. We find a stronger point 
estimate of the wage elasticity in this specification. We also provide results from specifications without countryxdataset dummies. In this case we obtain a similar estimate for the supply elasticity for tertiary education (1.86), and a larger but even less precise estimate for secondary education. Note that the public expenditure variable turns significant once estimating on variation across countries as well as within.

Since IV (a) is the specifications which includes all the exogenous variables otherwise in the model, we use these estimates when we construct our net supply measure. We need the supply equation primarily in order to obtain reasonable exogenous supply shifters in the wage equation estimated in the following section. There are three reasons why the lagged population share and public expenditure on higher education are expected to be exogenous in the wage equation. First, the three-year lag of the population share ensures that current movements in wages do not affect the instrument. Note also that the preferred models include country (and year) dummies, so that time invariant (and country) omitted variables, possibly correlated with both relative supply and relative wages, are swept out. Second, the use of population rather than labour force shares (supply) ensures that effects via labour force participation are removed. Third, using population rather than employment shares in the wage equation also removes potential effects via relative unemployment. Turning to public expenditure on education, it can be noted that it is based on decisions taken during the previous year. Furthermore, these decisions are made in the framework of a long term investment strategy. As a result, we argue that this variable is little affected by recent, transitory movements in relative wages.

\subsection{The Relative Wage Equation}

From the demand and supply equations we have calculated a demand shifter, a supply shifter and a net supply shifter ( $s$ - $d$ in equation (11)). The net supply shifter is calculated by predicting relative demand (model 1 in Table 5.1) and relative supply (models IV (a) of Table 5.3) and, then, subtracting the relative wage multiplied by the associated coefficients. The demand shifter includes "country times dataset" fixed effects and fixed year effects. The supply shifter includes the log of public expenditure on education, the share of the population with tertiary education three years ago and "country times dataset" fixed effects ${ }^{14}$.

\footnotetext{
${ }^{14}$ Both shifters also include a specific trend for ECHP data, a country specific time trend for Greece and Spain to account for some missing data; see notes to the tables.
} 
Table 5.4. Relative Wage regressions

\begin{tabular}{|c|c|c|c|c|c|}
\hline Ln relative wage (Tertiary/Primary) & $\begin{array}{l}\text { Model } 1 \\
\text { SUR }\end{array}$ & $\begin{array}{l}\text { Model } 2 \\
\text { SUR }\end{array}$ & $\begin{array}{l}\text { Model } 3 \\
\text { SUR }\end{array}$ & $\begin{array}{l}\text { Model } 4 \\
\text { SUR }\end{array}$ & $\begin{array}{l}\text { Modell } 5 \\
\text { IV }\end{array}$ \\
\hline \multirow{2}{*}{ Replacement-ratio } & 0.0257 & 0.0257 & 0.0212 & -0.0001 & $-0.0492^{*}$ \\
\hline & 0.0158 & 0.0156 & 0.0155 & 0.0141 & 0.0113 \\
\hline \multirow{2}{*}{ Employment-protection } & 0.0058 & 0.0085 & 0.0052 & -0.0003 & 0.0027 \\
\hline & 0.0098 & 0.0098 & 0.0106 & 0.0086 & 0.0111 \\
\hline \multirow{2}{*}{ Union-density } & -0.0147 & -0.0222 & -0.0142 & $0.0399^{*}$ & 0.0002 \\
\hline & 0.0224 & 0.0225 & 0.0230 & 0.0130 & 0.0117 \\
\hline \multirow{2}{*}{ Bargaining-coordination } & $-0.0808^{*}$ & $-0.0807^{*}$ & $-0.0682^{*}$ & $-0.0204 z$ & $-0.0489^{*}$ \\
\hline & 0.0197 & 0.0195 & 0.0250 & 0.0116 & 0.0177 \\
\hline \multirow{2}{*}{ Coordination in Year T } & & $-0.0218^{*}$ & & & \\
\hline & & 0.0120 & & & \\
\hline \multirow[t]{2}{*}{ B-coordinationXnet supply shifter } & & & $-0.0318^{*}$ & & \\
\hline & & & 0.0155 & & \\
\hline \multirow[t]{2}{*}{ U-densityXnet supply shifter } & & & 0.0176 & & \\
\hline & & & 0.0145 & & \\
\hline \multirow[t]{2}{*}{ Linear trend } & & & & & -0.0036 \\
\hline & & & & & 0.0047 \\
\hline \multirow{2}{*}{ Net supply shifter } & $-0.1459^{*}$ & $-0.1463^{*}$ & -0.0058 & $-0.0775^{\star}$ & -0.0212 \\
\hline & 0.0366 & 0.0365 & 0.0894 & 0.0200 & 0.0030 \\
\hline $\mathrm{R}$-square & 0.9737 & 0.9646 & 0.9646 & 0.9532 & 0.8218 \\
\hline \multicolumn{6}{|l|}{ Ln relative wage (Secondary/Primary) } \\
\hline \multirow{2}{*}{ Replacement-ratio } & 0.0071 & 0.0071 & 0.0014 & -0.0051 & $-0.0250^{\star}$ \\
\hline & 0.0071 & 0.0071 & 0.0075 & 0.0061 & 0.0052 \\
\hline \multirow{2}{*}{ Employment-protection } & -0.0058 & -0.0055 & -0.0063 & -0.0100 & -0.0069 \\
\hline & 0.0046 & 0.0046 & 0.0048 & 0.0038 & 0.0045 \\
\hline \multirow{2}{*}{ Union-density } & -0.0162 & -0.0171 & -0.0170 & 0.0094 & -0.0053 \\
\hline & 0.0101 & 0.0103 & 0.0113 & 0.0054 & 0.0086 \\
\hline \multirow{2}{*}{ Bargaining-coordination } & $-0.0281^{*}$ & $-0.0282^{*}$ & $-0.0257^{*}$ & 0.0051 & -0.0087 \\
\hline & 0.0100 & 0.0100 & 0.0114 & 0.0053 & 0.0104 \\
\hline \multirow{2}{*}{ Coordination in Year T } & & -0.0025 & & & \\
\hline & & 0.0054 & & & \\
\hline \multirow{2}{*}{ B-coordinationXnet supply shifter } & & & $-0.0365^{*}$ & & \\
\hline & & & 0.0146 & & \\
\hline \multirow{2}{*}{ U-densityXnet supply shifter } & & & 0.0218 & & \\
\hline & & & 0.0142 & & \\
\hline \multirow{2}{*}{ Linear trend } & & & & & -0.0007 \\
\hline & & & & & 0.0019 \\
\hline \multirow{2}{*}{ Net supply shifter } & $-0.1459^{*}$ & $-0.1463^{*}$ & -0.0058 & $-0.0775^{\star}$ & -0.0086 \\
\hline & 0.0366 & 0.0365 & 0.0894 & 0.0200 & 0.0023 \\
\hline R-square & 0.9577 & 0.9577 & 0.9590 & 0.9480 & 0.7802 \\
\hline Country and time dummies & yes & yes & yes & yes & no \\
\hline Cross equation correlation of residual & 0.5304 & 0.5526 & 0.5391 & 0.5801 & \\
\hline Cluster by country & & & & & yes \\
\hline Observations & 117 & 117 & 117 & 117 & 117 \\
\hline
\end{tabular}

Note: $\left(^{*}\right)$ statistically significant at the 5 percent level, while $z$ denotes a coefficient significant at the 10 percent level. Estimates are weighted using the number of observations per countryXyear in the original dataset used to produce the secondary data set. The models also include a specific time trend for Greece. 
To account for other factors affecting wage formation, we also include the unemployment replacement ratio, an index of employment protection, as well as variables reflecting unionisation and coordination in bargaining in the models. Table 5.4 reports the main wage regression results. The models are estimated using a seemingly unrelated regression framework (SUR), taking into account the possible correlation between the two different measures of relative wages. We also include a cross equation restriction that the effect of the net supply shifter should be equal for the two educational groups. (The p-value of the hypothesis of common effects was 0.19 when estimating in a flexible version of model 1.) Since the dependent variable is estimated from the primary data sets, we weight the observations with the number of observations in the particular yearxdataset cell in the primary data sets.

The upper panel reports the results for tertiary education. We do not find significant effects of the replacement ratio or employment protection on the tertiary/primary wage premium. We do find a significant negative effect of bargaining coordination, but not a significant effect of union density on the tertiary wage premium. Increasing coordination by one point (the index is normalized to take values between 0 and 10) decreases the tertiary wage premium by $0.08 \log$ points. The point estimate of the net supply shifter is -0.15 .

The lower panel reports the results for secondary education. Again, there is a significant negative effect of bargaining coordination, but the effect is considerably smaller in size than the effect reported for tertiary education, -0.028 versus -0.081 . The point estimate of the net supply shifter is again - 0.15 . Our coordination measure is a time-varying aggregate measure (average over the last 20 years) taken from Wallerstein (1990). Wallerstein argues that coordination affects wage differentials over time and that, for this reason, an aggregate measure which varies over time should be preferable. In order to check this, in model 2, we add a (time-varying) contemporaneous coordination of bargaining variable, i.e. recorded in the same year as the wage observation. In accordance with Wallerstein's claim, we find a negative, but much smaller effect of the contemporaneous measure of coordination, while the coefficient for the aggregate measure remains unchanged.

In model 3 we introduce interaction effects between net supply shifter and the bargaining variables. We find a negative interaction effect between coordination in bargaining and net supply, and a positive but not statistically significant, interaction effect between union density and net supply. An interpretation of this result could be that strong unions are able to "shield" bargaining outcomes from labour market influences; however, when the level of coordination is high, labour market conditions become relevant again and strongly affect the 
outcomes. This result would be consistent with a bargaining model where decentralised bargaining unions do not care about overall unemployment, while centralised unions internalise unemployment into the bargain.

Since the models include year dummies, net supply is mostly identified by changes in the supply shifter. In model 4, we display the results from a model which does not include year dummies. Time is here only allowed to work through the demand shifter in the net supply variable. We find a slightly weaker impact of net supply on both relative wages. Furthermore, the effect of bargaining coordination diminishes considerably when excluding controls for time. However, since the year dummies are highly significant in models 1-3 we regard this model as a misspecification, and report it only to increase the transparency of the results.

For completeness, the last model shows an instrumental variable specification without country $x$ data and year fixed effects (a linear trend is included to replace the year dummies). Identifying effects using also cross country variation, we now find a significant wage compressing effect of the replacement ratio. The effect of the net supply shifter is very much reduced and the wage compressing effect of bargaining coordination is reduced by almost a half.

The fact that we use estimated values of net supply in the wage equations may be of some worry. In order to test for robustness, we report in Panel A of Table 5.5. results from four different experiments. The first column reports the results from a regression where relative employment is instrumented using the net supply shifter as instrument. According to Pagan (1984) this procedure should provide us with better estimators of the standard error of the coefficients when we use a derived predictor (net supply) as a regressor. The next column reports from a specification where relative employment is instrumented using lagged population share and the log of public expenditures on higher education as instruments. The results of these two experiments are very similar to the ones reported in model 1 of Table 5.1, but give higher estimates of the impact of relative supply (around 0.21 rather than 0.15 ) and of bargaining coordination ( 0.11 versus .08).

Column 3 reports from a third experiment. In this model net supply is calculated from a few a priori assumptions, instead of using the estimated values of relative wage elasticities from the supply and demand equation. This procedure is similar to the one used by Acemoglu (2003). We assume here that the elasticity of substitution between the educational levels is 1.4 (the preferred estimate of Autor and Katz, used by Acemoglu, 2003) and that the elasticity of 
relative supply with respect to relative wages is zero. This specification gives very similar results to the one reported in model 1 of Table 5.1.

An even more direct way of assessing the impact of supply is to include the lagged value of the share of population directly into the wage equation (in this model both country and year dummies are included to keep track of changes in demand). The third model reports results from such a specification, and again the results are very similar to the ones reported in Table 5.1. The wage equations can thus be considered to be rather robust to various ways of modelling the impact of market forces on relative wages.

A major worry with the type of study we have undertaken is the large heterogeneity in terms of both levels and effects, relative to the sample size. We have reduced this problem to a very large extent by identifying our results in models including both country( $x$ dataset $)$ and year fixed effects. A considerable part of the heterogeneity is, thus, removed, which is of course the reason why we have extremely high R-squares. However, once removing such a large part of the variation in the data set, relying only on within country changes in the variables, the concern about heterogeneous effects as well as measurement errors arises. In order to further check the validity and robustness of our results, we include in panel B of Table 5.5 a set of regression results derived from sub-samples of the full data. Naturally, with only 117 observations from 16 datasets from 12 countries, there are severe limitations regarding the number of restrictions that can be imposed on the sample. The following subsamples are created in order to check against two types of worries: (a) that the combination of data sets constitutes a problem, and, (b) that there are particular groups of countries that are likely to drive the results.

The first two columns of Panel B report results from a) excluding the ECHP data from the sample and, thus, relying solely on regressions run on national data sets and b) excluding ECHP data where we have information from national data sets. In column 3, we remove the Nordic countries (Denmark, Finland, Norway and Sweden) and in column 4 the southern countries (Greece, Italy and Spain). In the last column we run our model on the large countries only (UK, Germany, Spain, Italy and France). The coefficient for net supply for tertiary appears quite robust to changes in the data set, ranging from 0.085 to 0.155 . The coefficients for bargaining coordination also appear very robust. However, the coefficient for union density and replacement ratio appear to shift around somewhat, depending on the sample. There appears to be some heterogeneity in terms of the effects of these variables, but given the number of observations and the focus of this paper, we are reluctant to pursue this 
topic further here. All in all the results with respect to net supply and bargaining coordination appear to be very robust across both specifications as well as data sets.

Table 5.5. Relative Wage regressions Robustness checks

\section{A. SUPPLY INDICATORS}

\begin{tabular}{|c|c|c|c|c|}
\hline & Model 1 & Model 2 & $\begin{array}{l}\text { Modell } 3 \\
\text { Autor \& Katz } \\
\text { elasticity of } \\
\text { subst. }\end{array}$ & $\begin{array}{l}\text { Model } 4 \\
\text { Lagged supply (t- } \\
\text { 3) }\end{array}$ \\
\hline Ln relative wage (Tertiary/Primary) & SUR & SUR & SUR & SUR \\
\hline \multirow{2}{*}{ Replacement-ratio } & 0.0339 & 0.0324 & 0.0264 & 0.0218 \\
\hline & 0.0163 & 0.0163 & 0.0158 & 0.0157 \\
\hline \multirow{2}{*}{ Employment-protection } & 0.0137 & 0.0125 & 0.0049 & 0.0013 \\
\hline & 0.0104 & 0.0104 & 0.0097 & 0.0096 \\
\hline \multirow{2}{*}{ Union-density } & -0.0126 & -0.0113 & -0.0144 & -0.0095 \\
\hline & 0.0222 & 0.0222 & 0.0223 & 0.0223 \\
\hline \multirow{2}{*}{ Bargaining-coordination } & -0.1183 & -0.1132 & -0.0805 & -0.0661 \\
\hline & 0.0251 & 0.0249 & 0.0196 & 0.0187 \\
\hline \multirow{2}{*}{ Ln(T/P)_Employment } & -0.2263 & -0.2107 & -0.1637 & -0.1226 \\
\hline & 0.0548 & 0.0542 & 0.0406 & 0.0377 \\
\hline $\begin{array}{l}\sigma / \wedge \sigma \\
\text { Ln relative wage (Secondary/Primary) }\end{array}$ & 1.07 & 1.07 & & \\
\hline \multirow{2}{*}{ Replacement-ratio } & 0.0355 & 0.0330 & 0.0076 & 0.0079 \\
\hline & 0.0112 & 0.0111 & 0.0072 & 0.0075 \\
\hline \multirow{2}{*}{ Employment-protection } & -0.0109 & -0.0111 & -0.0059 & -0.0077 \\
\hline & 0.0042 & 0.0043 & 0.0046 & 0.0046 \\
\hline \multirow{2}{*}{ Union-density } & -0.0236 & -0.0222 & -0.0182 & -0.0191 \\
\hline & 0.0107 & 0.0108 & 0.0103 & 0.0109 \\
\hline \multirow{2}{*}{ Bargaining-coordination } & -0.0586 & -0.0547 & -0.0297 & -0.0249 \\
\hline & 0.0156 & 0.0155 & 0.0102 & 0.0104 \\
\hline \multirow{2}{*}{ Ln(S/P)_Employment } & -0.2263 & -0.2107 & -0.1637 & -0.1226 \\
\hline & 0.0548 & 0.0542 & 0.0406 & 0.0377 \\
\hline$\sigma / \wedge \sigma$ & 1.11 & 1.10 & & \\
\hline
\end{tabular}

Cross equations correlation of residuals

0.4955

N. obs

117

117

117

117 


\section{B. DIFFERENT SUB SAMPLES}

\begin{tabular}{|c|c|c|c|c|c|}
\hline \multirow[b]{2}{*}{$\begin{array}{l}\text { Ln relative wage } \\
\text { (Tertiary/Primary) }\end{array}$} & \multicolumn{5}{|c|}{ Excluding the following: } \\
\hline & ECHP-data & $\begin{array}{l}\text { Overlapping } \\
\text { ECHP-data }\end{array}$ & Nordic & South & Small \\
\hline \multirow{2}{*}{ Replacement-ratio } & 0.0336 & 0.0283 & $0.0516^{\star}$ & $-0.0463^{*}$ & $0.0585^{*}$ \\
\hline & 0.0202 & 0.0178 & 0.0193 & 0.0225 & 0.0229 \\
\hline \multirow{2}{*}{ Employment-protection } & 0.0141 & 0.0066 & 0.0180 & 0.0021 & 0.0228 \\
\hline & 0.0131 & 0.0109 & 0.0115 & 0.0088 & 0.0140 \\
\hline \multirow{2}{*}{ Union-density } & -0.0364 & -0.0194 & 0.0726 & 0.0298 & 0.0747 \\
\hline & 0.0289 & 0.0246 & 0.0441 & 0.0197 & 0.0536 \\
\hline \multirow{2}{*}{ Bargaining-coordination } & $-0.1033^{*}$ & $-0.0821^{*}$ & $-0.0993^{\star}$ & $-0.0758^{*}$ & $-0.1057^{*}$ \\
\hline & 0.0264 & 0.0210 & 0.0213 & 0.0162 & 0.0268 \\
\hline \multirow{2}{*}{ Net supply shifter } & $-0.1376^{*}$ & $-0.1517^{*}$ & $-0.1554^{\star}$ & $-0.0849^{*}$ & $-0.1306^{*}$ \\
\hline & 0.0451 & 0.0375 & 0.0426 & 0.0366 & 0.0529 \\
\hline \multirow[b]{2}{*}{$\begin{array}{l}\text { Ln relative wage } \\
\text { (Secondary/Primary) }\end{array}$} & \multicolumn{5}{|c|}{ Excluding the following: } \\
\hline & ECHP-data & $\begin{array}{l}\text { Overlapping } \\
\text { ECHP-data }\end{array}$ & Nordic & South & Small \\
\hline \multirow{2}{*}{ Replacement-ratio } & $0.0113^{*}$ & $0.0118^{*}$ & $0.0127^{\star}$ & -0.0258 & 0.0066 \\
\hline & 0.0087 & 0.0074 & 0.0092 & 0.0138 & 0.0114 \\
\hline \multirow{2}{*}{ Employment-protection } & $-0.0103 z$ & -0.0076 & -0.0037 & -0.0064 & -0.0084 \\
\hline & 0.0059 & 0.0047 & 0.0056 & 0.0056 & 0.0072 \\
\hline \multirow{2}{*}{ Union-density } & $-0.0223^{*}$ & $-0.0200^{*}$ & 0.0263 & 0.0028 & 0.0417 \\
\hline & 0.0124 & 0.0103 & 0.0206 & 0.0121 & 0.0259 \\
\hline \multirow{2}{*}{ Bargaining-coordination } & $-0.0283^{\star}$ & $-0.0298^{*}$ & $-0.0341^{*}$ & $-0.0232^{*}$ & $-0.0248^{*}$ \\
\hline & 0.0126 & 0.0101 & 0.0113 & 0.0104 & 0.0148 \\
\hline \multirow{2}{*}{ Net supply shifter } & $-0.1376^{*}$ & $-0.1517^{*}$ & $-0.1554^{\star}$ & $-0.0849^{*}$ & $-0.1306^{*}$ \\
\hline & 0.0451 & 0.0375 & 0.0426 & 0.0366 & 0.0529 \\
\hline
\end{tabular}

Note: $\left({ }^{*}\right)$ statistically significant at the 5 percent level, while $z$ denotes a coefficient significant at the 10 percent level.

Estimates are weighted using the number of observations per countryxyear in the original dataset used to produce the secondary data set.

\section{Within group wage dispersion}

In this section we analyse the conditional wage dispersion within educational group. As discussed earlier, the growth in participation in tertiary education could result in skills erosion implying a widening of the conditional wage dispersion within higher education. The reallocation of ability across education level - as tertiary education expands -- could also foster a compression in the wage dispersion within the lower education level. More specifically, a larger share of the population with tertiary education qualifications should lead to a drop in the bottom of the conditional distribution for tertiary education employees and to 
a compression at the top of the distribution for secondary education workers. We test his proposition by relating the inter-quantile ranges of log wages within each educational group to the share of the population that has attained tertiary education.

The inter-quantile range, Q9010, is defined as the log of the predicted wage, conditional on experience, gender, sector and industry for the $9^{\text {th }}$ decile point divided by the predicted wage for the $1^{\text {st }}$ decile point of the conditional wage distribution (see section 4.2. for detailed definition). Table 6.1 reports the average measures of relative wages within each educational group for each country.

Table 6.1. Conditional Wage Dispersion. Country Averages and European Time Trend

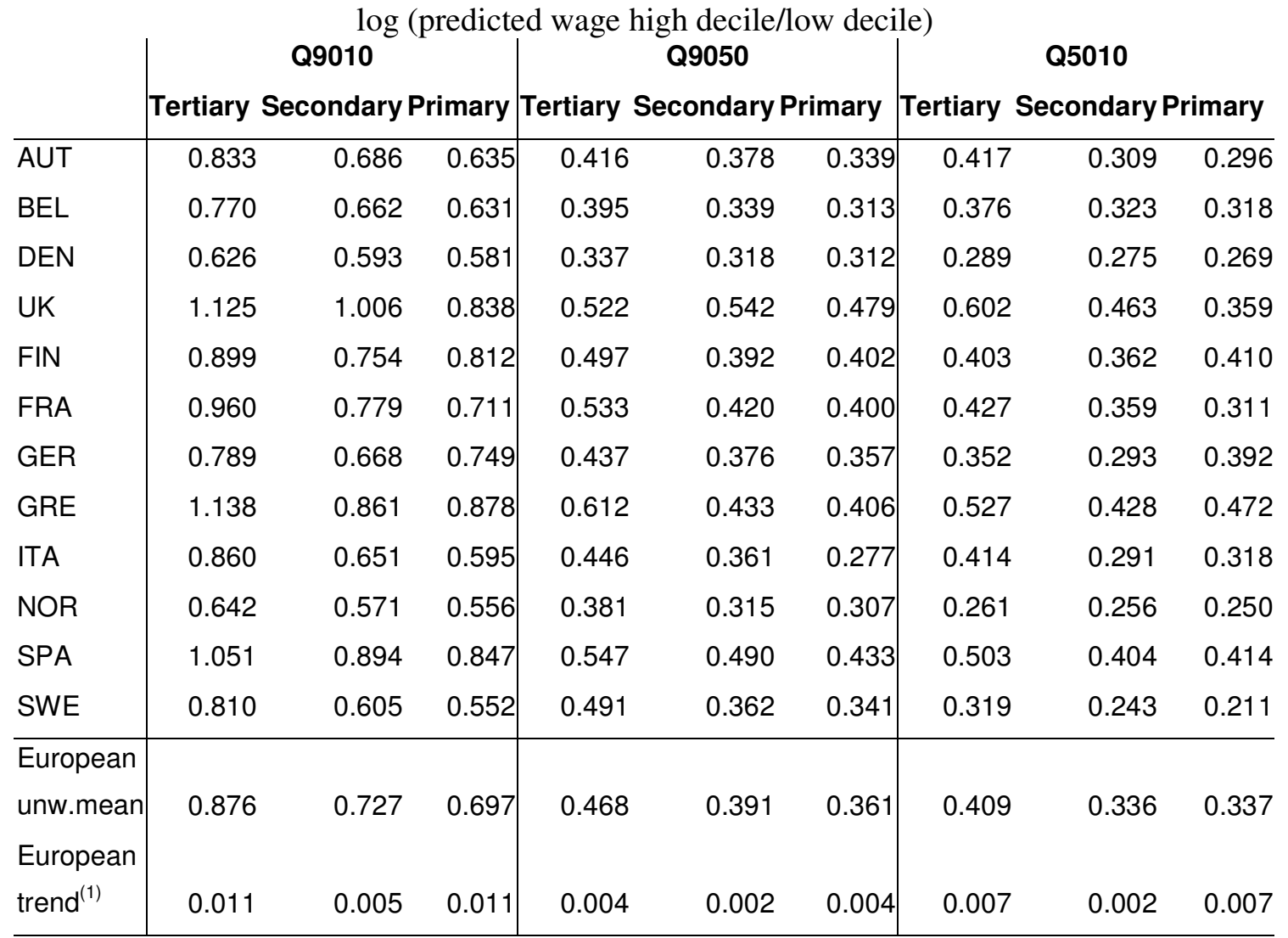

Note: Country averages are simple means of all observations from a country. European time trend is the linear trend coefficient from separate regressions of each relative predicted decile wage on countryxdataset fixed effects a time trend and a separate trend for ECHP data (weighted with population weights) In none of the regression did a second order term turn out significant, and we thus limit ourselves to report from a specification with the (log) linear trend. Conditional wage dispersion is calculated from the result of quantile regressions. It is calculated for a private sector male employee, working in manufacturing with 10 years of experience.

$\mathrm{Qj}_{0} \mathrm{i}_{0}$ is estimated using the whole sample of employees within each educational group, and then estimates are derived for a private sector male worker, employed in manufacturing, with 10 years of experience. The average conditional log wage differential Q9010 is 0.88 for tertiary education, 0.73 for secondary education and 0.70 for primary education, indicating 
larger within-group conditional wage dispersion for tertiary education. An estimated European trend indicates a growth in within group wage dispersion of almost 1 percent per year for tertiary and primary education and about half of this within secondary education. The average Q9050 is higher than Q5010 within each educational group - especially, for tertiary education graduates - a result which is reflected in the country specific averages as well, with very few exceptions. Between country differences are in line with other studies of wage differentials, displaying large differences in countries like the UK, Greece and Spain and particularly small differences in the Scandinavian countries, Denmark, Norway and Sweden. In the next step we shall use differences in the development of these relative wage indicators and the share of the population with tertiary education between countries, also controlling for labour market institutions and a trend variable picking up common developments in technology across Europe.

\subsection{Results}

The first block of Table 6.2 displays the results from regressions of the Q9010 range within each educational group ${ }^{15}$. Looking at the Q9010 differential we find that bargaining coordination has a compressing effect in the group of tertiary education graduates and that employment protection compresses wages for all three educational groups ${ }^{16}$. The log of the share of the population with tertiary education has a negative effect on the conditional wage dispersion within all three educational groups (insignificant for secondary and tertiary education). Thus, these results offer no support to the skills erosion hypothesis related to growth in attainment of tertiary education. We find that about half of the positive trend in wage dispersion can be explained by changes in bargaining institutions and labour market policies. The remaining trend is about two thirds of the raw European average reported Table 6.1, and no longer statistically significant.

The next two blocks report results on the Q9050 and Q5010 differentials. The compressing effect of bargaining coordination appears to be stronger in the upper part (Q9050) than for the bottom part of the distribution (Q5010). For the bottom of the distribution of primary education graduates, we even find a significantly positive effect of bargaining coordination, perhaps indicating a strengthening of the bargaining position of the

\footnotetext{
15 The models also include fixed "country $x$ dataset" dummies and a time trend for ECHP-data as well as specific time trends for Greece and Spain where some of the institutional variables were missing.

${ }^{16}$ This finding is consistent with the implications of the model developed by Bertola and Rogerson (1997) where the presence of employment protection measures is found to be complementary to wage compression. In a study covering 20 OECD countries, Lucifora (2000) reports similar results.
} 
median worker among the unskilled (primary education). Employment protection, on the other hand, appears to have a wage compressing effect at the bottom (Q5010) rather than the top (Q9050) of the wage distribution. However, the compressing effect of employment protection is as strong within tertiary education as within the other groups. Again, we fail to see the pattern predicted by the skills-erosion hypothesis. In particular, there is no evidence of a drop in the bottom of the wage distribution among tertiary education graduates associated with an increase in the share of the population with tertiary education.

We have also undertaken similar regressions, where the population share of tertiary education is instrumented by historical levels (three years back) as well as by public expenditure on higher education. The point estimates indicate a zero effect on Q9010 of a larger share of workers with tertiary education qualifications, but that the zero-result is an aggregate of an increase in wage dispersion at the top and a decrease in wage dispersion at the bottom of the distributions. These results were the opposite of what is predicted by the skillserosion hypothesis, but cannot be given much weight since almost all coefficients were insignificant. Since Hausman-tests suggested that endogeneity was not an important problem in these regressions, we have chosen not to report from the instrumental variable specifications.

Table 6.2. Conditional wage dispersion within educational group

Dependent variable: $\log$ (predicted wage high decile/low decile) Fixed country $x$ dataset effect models

\begin{tabular}{lrrrrrr}
\hline Variable & \multicolumn{3}{c}{ Tertiary } & \multicolumn{2}{c}{ Q9010 Secondary } & \multicolumn{2}{c}{ Primary } \\
\cline { 2 - 7 } Linear Trend-Year & 0.0081 & & 0.0020 & & 0.0063 & \\
& 0.0051 & & 0.0058 & & 0.0115 & \\
Bargaining-coordination & $-0.0715^{*}$ & $-0,1382^{*}$ & -0.0001 & $-0,0308 z$ & 0.0559 & 0,0174 \\
& 0.0186 & 0,0228 & 0.0142 & 0,0146 & 0.0266 & 0,0327 \\
Union Density & -0.0167 & $-0,0567$ & -0.0053 & $-0,0117$ & -0.0169 & $-0,0343$ \\
& 0.0327 & 0,0200 & 0.0234 & 0,0211 & 0.0373 & 0,0418 \\
Employment protection & $-0.0477^{*}$ & $-0,0267^{*}$ & $-0.0375^{*}$ & $-0,0268 z$ & -0.0526 & $-0,0340$ \\
& 0.0183 & 0,0113 & 0.0139 & 0,0135 & 0.0223 & 0,0243 \\
Replacement ratio & -0.0081 & $-0,0013$ & -0.0009 & $-0,0041$ & 0.0057 & 0,0112 \\
& 0.0302 & 0,0094 & 0.0210 & 0,0101 & 0.0324 & 0,0237 \\
Ln(Tertiary Population Share) & $-0.1595^{*}$ & $-0,2822^{*}$ & -0.0654 & $-0,1057$ & -0.0691 & $-0,2016$ \\
Year dummies & 0.0798 & 0,1023 & 0.1040 & 0,1404 & 0.1768 & 0,2044 \\
\hline & & Yes & & Yes & & Yes
\end{tabular}


Q9050

\begin{tabular}{|c|c|c|c|c|c|c|}
\hline \multirow{3}{*}{ Linear Trend-Year } & \multicolumn{2}{|r|}{ Tertiary } & \multicolumn{2}{|r|}{ Secondary } & & Primary \\
\hline & 0.0024 & & 0.0012 & & 0.0009 & \\
\hline & $(0.0041)$ & & $(0.0019)$ & & $(0.0048)$ & \\
\hline \multirow{2}{*}{ Bargaining-coordination } & $-0.0430^{*}$ & $-0,0751^{*}$ & -0.0124 & $-0,0302^{*}$ & 0.0137 & $-0,0070$ \\
\hline & $(0.0112)$ & 0,0190 & $(0.0109)$ & 0,0146 & $(0.0175)$ & 0,0178 \\
\hline \multirow{2}{*}{ Union Density } & 0.0041 & $-0,0039$ & -0.0123 & $-0,0154$ & -0.0115 & $-0,0176$ \\
\hline & $(0.0198)$ & 0,0175 & $(0.0115)$ & 0,0104 & $(0.0129)$ & 0,0185 \\
\hline \multirow{2}{*}{ Employment protection } & -0.0154 & $-0,0213^{*}$ & $-0.0154^{*}$ & $-0,0116$ & -0.0173 & $-0,0105$ \\
\hline & $(0.0098)$ & 0,0070 & $(0.0064)$ & 0,0071 & $(0.0099)$ & 0,0107 \\
\hline \multirow{2}{*}{ Replacement ratio } & 0.0152 & 0,0138 & 0.0035 & 0,0022 & -0.0081 & $-0,0044$ \\
\hline & $(0.0171)$ & 0,0115 & $(0.0120)$ & 0,0062 & $(0.0151)$ & 0,0124 \\
\hline \multirow{2}{*}{ Ln(Tertiary Population Share) } & -0.0561 & $-0,0757 z$ & -0.0427 & $-0,0845 z$ & 0.0042 & $-0,0705$ \\
\hline & $(0.0748)$ & 0,0403 & $(0.0346)$ & 0,0459 & $(0.0684)$ & 0,0626 \\
\hline
\end{tabular}

Q5010

\begin{tabular}{|c|c|c|c|c|c|c|}
\hline \multirow{3}{*}{ Linear Trend-Year } & \multicolumn{2}{|r|}{ Tertiary } & \multicolumn{2}{|c|}{ Secondary } & \multicolumn{2}{|r|}{ Primary } \\
\hline & 0.0049 & & 0.0010 & & 0.0066 & \\
\hline & $(0.0039)$ & & $(0.0057)$ & & $(0.0088)$ & \\
\hline \multirow{2}{*}{ Bargaining-coordination } & $-0.0305^{\star}$ & $-0,0631^{*}$ & 0.0128 & $-0,0006$ & $0.0455^{\star}$ & 0,0244 \\
\hline & $(0.0112)$ & 0,0171 & $(0.0094)$ & 0,0109 & $(0.0146)$ & 0,0206 \\
\hline \multirow{2}{*}{ Union Density } & -0.0229 & $-0,0528^{*}$ & 0.0076 & 0,0037 & -0.0019 & $-0,0167$ \\
\hline & $(0.0176)$ & 0,0189 & $(0.0147)$ & 0,0160 & $(0.0257)$ & 0,0340 \\
\hline \multirow{2}{*}{ Employment protection } & $-0.0333^{*}$ & $-0,0054$ & $-0.0219^{*}$ & $-0,0152$ & $-0.0336^{*}$ & $-0,0235$ \\
\hline & $(0.0130)$ & 0,0081 & $(0.0074)$ & 0,0101 & $(0.0115)$ & 0,0162 \\
\hline \multirow{2}{*}{ Replacement ratio } & -0.0246 & $-0,0150$ & -0.0042 & $-0,0063$ & 0.0160 & 0,0156 \\
\hline & $(0.0173)$ & 0,0101 & $(0.0091)$ & 0,0096 & $(0.0153)$ & 0,0144 \\
\hline \multirow{2}{*}{ Ln(Tertiary Population Share) } & -0.0904 & $-0,2065^{*}$ & -0.0256 & $-0,0212$ & -0.0947 & $-0,1310$ \\
\hline & $(0.0627)$ & 0,1094 & $(0.0976)$ & 0,1247 & $(0.1408)$ & 0,1533 \\
\hline Year dummies & & Yes & & Yes & & Yes \\
\hline \multicolumn{7}{|c|}{$\begin{array}{l}\text { Note: }\left({ }^{*}\right) \text { statistically significant at the } 5 \text { percent level, while } z \text { denotes a coefficient significant at the } 10 \text { percent level. } \\
\text { Estimates are weighted using the number of observations per countryxyear in the original dataset used to produce the } \\
\text { secondary data set. } \\
\text { All models include fixed countryxdata set effects, a time trend for ECHP data, and Greece. Predicted wage differential is } \\
\text { calculated for a private sector male employee, working in manufacturing with } 10 \text { years of experience. Standard errors are } \\
\text { calculated using cluster by country. }\end{array}$} \\
\hline
\end{tabular}

As discussed in the previous section, analyses of this type, utilising a panel of data from different countries are susceptible to the criticism that there is too much heterogeneity in the population relative to the degrees of freedom in the data. The fact that we rely on fixed effect estimators and, further, allow for a trend variable, removes most of this heterogeneity. However, to check if our results are sensitive to the inclusion or exclusion of certain data 
points, we report in Table 6.3 the results for Q9010 tertiary education, based on different subsamples of population. We find that the main results do not rely on the inclusion of the Nordic countries, the Southern countries, small or large countries or of the inclusion of ECHP-data in the analysis: The point estimates for the effect of the share of tertiary education graduates in the population on the conditional wage dispersion within tertiary education is negative and often insignificant. Again, the results indicate that we can rely on the results of Table 6.2 for our conclusions.

All in all we find that bargaining coordination compress wages at the top of the distribution, in particular for the group of tertiary education graduates, while employment protection compresses wages at the bottom of the distribution. We are unable to obtain support for the skills erosion hypothesis, as the share of tertiary education has no systematic effects on the conditional wage distribution in any part of the distribution.

Table 6.4. Effect of population share on the conditional Q9010 dispersion.

Sensitivity test, different samples, Tertiary education

Dependent variable: Q9010 $=\log \left(\right.$ predicted wage $9^{\text {th }}$ decile $/ 1^{\text {st }}$ decile)

Coefficient

Standard error In(tertiary population share)

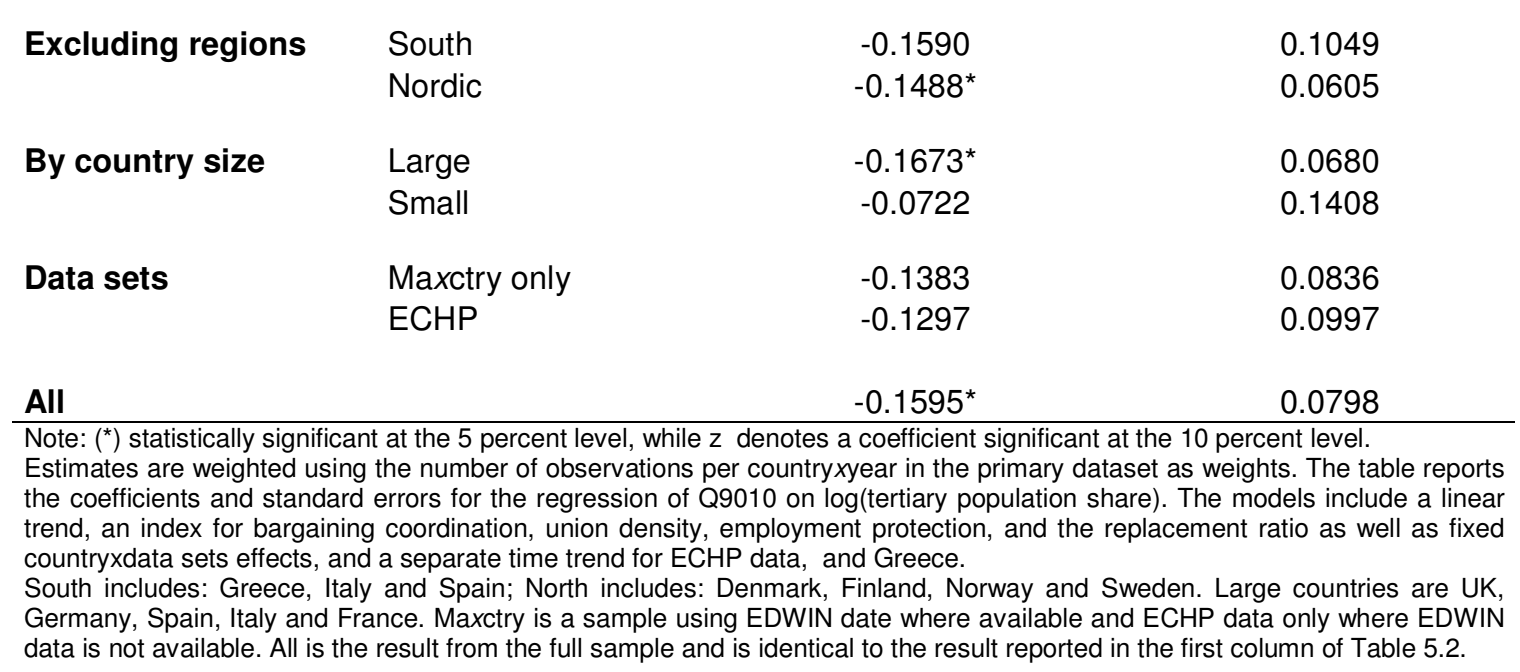

\section{Concluding discussion}

In this paper, we investigate the effects of the boom in education on the wage structure using a long panel covering 12 European countries. We focus on the role played by market and institutional factors both on the structure of wage differentials, as well as on the conditional wage dispersion within each educational group. We show that the significant 
increase in relative supply of tertiary education would have implied - ceteris paribus - a marked compression of the wage premium attached to tertiary education. In particular, analysing the wage premium attached to higher education, we provide an estimate of the elasticity of substitution -- using both country and time fixed effects -- between tertiary and secondary education versus primary education, of about 2 . Given that the increase in the relative supply of tertiary education, from 1985 to 2000 in the countries considered, was on average 20 percent; the supply shock would have implied a drop of about 40 percent in the wage premium attached to tertiary education. Conversely, empirical evidence shows that the wage premium of tertiary education remained remarkably stable in most European economies, thus suggesting that the expansion of the educational system was closely matched by demand shifts originating from (skill biased) technological change. Indeed, without this growth in tertiary education, wage premiums for education would have risen considerably.

Our main conclusion is thus that there are no signs from the wage structure that the expansion of the educational system in the European labour markets has not been matched by a similar growth in demand. This observation is valid on average as well as in the tails of the distribution of individuals (or jobs) within each educational group.

Next, we explore the impact of the boom in education on the conditional wage dispersion within each educational group. Among the leading explanations for the increase in within group wage dispersion, as a result of the expansion of education, we investigated whether skills erosion and over-education may account for the observed patterns. Note that even if the development of the average return to education over time indicates an increase in demand, skills erosion or over-education may still affect the lower part of the wage distribution for higher education. In this context, we document the existence of an increasing trend in within-group wage inequality and, in line with previous studies, this trend is shown to be particularly large for tertiary education.

However, we do not find evidence in favour of the skill erosion hypothesis within the group of tertiary education, nor evidence of increasing "over-education" in Europe. In particular, exploiting differences in timing and strength of the expansion of tertiary education between countries and using fixed country effects, we find an insignificant (negative) impact of an increase in the volume of tertiary education on the conditional within-group wage dispersion.

Finally, we investigated the role of institutions versus market forces in the shaping of the wage distribution. We found that about half of the positive trend in conditional wage dispersion may be explained by changes in bargaining institutions and labour market policies. 
Contrary to the common perception, our results show that bargaining coordination tends to compress the upper part of the wage distribution rather than the bottom part. This effect is illustrated both by the (larger) compressing effect of bargaining coordination on the wage premium attached to tertiary education as opposed to secondary education; as well as by the (larger) effect on the conditional wage dispersion within tertiary education as opposed to within lower education. Also, within tertiary education, the upper part of the wage distribution is found to be the most affected. Conditional on the above, we find no consistent or statistically significant patterns with respect to either unionisation or the replacement-ratio.

Our results may have interesting implications for education policies in the European Union. The evolution of trade and technological developments are going to keep up the pressure on the performance of the labour market in European countries. It is important that the supply of higher education continues to keep pace with growth in demand. While the issues of over-education and skills erosion have been highly debated, there is no evidence from the earnings structure so far of a positive relationship between over-education and the level of supply of higher education Furthermore, our results show that labour market institutions like coordination in bargaining and employment protection have an equalizing effect on relative wages in the labour market, mitigating the impact of technological change on earnings inequality. Wage compression also works as a "subsidy" on high skilled labour relative to low skilled labour, which again may further stimulate the demand for high-skilled workers relative to low skilled workers in the labour market. However, wage compression reduces incentives for students to undertake long education. A combination of public student support and institutions in the labour market that promote wage compression may thus provide both less inequality and high levels of investments in human capital, as we have seen in many of the European countries. 


\section{References}

Acemoglu, D. (1998), "Why Do New Technologies Complement Skills? Directed Technical Change and Wage Inequality," Quarterly Journal of Economics, 113, 1055-1089.

Acemoglu, D. (2002) “Technical Change, Inequality and the Labor Market." Journal of Economic Literature 40 (March): 7-72.

Acemoglu, D. (2003) "Labor- and Capital-Augmenting Technical Change", Journal of European Economic Association, 1, 1-40.

Autor, D.H., Lawrence F. Katz, and A.B. Krueger (1998) "Computing Inequality: Have Computers Changed the Labor Market?” Quarterly Journal of Economics 113, 11691213.

Katz, L.F. and D.H. Autor (1999) "Changes in the Wage Structure and Earnings Inequality" in O. Ashtenfelter and D. Card, (eds.) Handbook of Labor Economics, Vol. 3A, Amsterdam: North-Holland.

Autor, D.H., L.F. Katz, and M.S. Kearney (2005) "Trends in US Wage Inequality: Reassesing the Revisionists", National Bureau of Economic Research, Working Paper no. 11627.

Barro, R. and J-W. Lee (1996) "International Measures of Schooling Years and Schooling Quality." American Economic Review Papers and Proceedings 86(2), pp. 218-23.

Barro, R. and J-W. Lee (2000). "International data on educational attainment, updates and implications." National Bureau of Economic Research, Working Paper no. 7911. (http://www.nber.org/papers/w7911).

Barth, E., Roed, M. (1999), "The Return to Human Capital in Norway: A Review of the Literature", Asplund R. (ed.) Returns to human capital in Europe: A literature review, ETLA - The Research Institute of the Finnish Economy, Helsinki, 227-58.

Bertola, G. and Rogerson, R. (1997), "Institutions and Labor Reallocation", European Economic Review, 41 (6), 1147-71

Bertola, G., Boeri, T. and S. Cazes (2000), "Employment protection in Industrialized countries: the case for new indicators", International Labor Review, 139, 57-72.

Bertola, G., F. Blau and L. Kahn (2002), "Comparative Analysis of Labor Market Outcomes: Lessons for the US from International Long-Run Evidence" in A. Krueger and R. Solow (eds.), The Roaring Nineties: Can Full Employment Be Sustained?, Russell Sage and Century Foundations, 159-218

Blanchard, O. and Wolfers J. (2000), "The Role of Shocks and Institutions in The Rise of European Unemployment: The Aggregate Evidence", Economic Journal, 110, 1-33

Blau, F. D. and Kahn, L. M. (1996), 'International differences In Male Wage Inequality: Institutions Versus Market Forces', Journal of Political Economy, 104, 791-837.

Blau, F. and Kahn L. (2000) "Gender Differences in Pay", NBER Working Paper 7732, National Bureau of Economic Research.

Bound, John and George Johnson (1992) "Changes in the Structure of Wages in the 1980s: An Evaluation of Alternative Explanations.” American Economic Review, 82, 371-92. 
Brunello, G. Comi, S. and Lucifora C. (2000) "College Wage Gap in 10 European Countries: Evidence from Two Cohorts”, IZA Discussion Paper No. 228, Bonn.

Buchinsky, M. (1994), “Changes in the U.S. Wage Structure 1963 - 1987: Application of Quantile Regression.” Econometrica, 62(2), 405 - 458.

Card, D. and J.E. DiNardo, (2002), "Skill-Biased Technological Change and Rising Wage Inequality: Some Problems and Puzzles." Journal of Labor Economics 20 (October): 733-83.

Card, D. and T. Lemieux (2001) "Can Falling Supply Explain the Rising Return to College for Younger Men?" Quarterly Journal of Economics 116, 705-46.

Dupuy, A. and L. Borghans, (2003) "Supply and Demand, Allocation and Wage Inequality: An International Comparison" Applied Economics, 2005, 37 (9), 1073-1088

Devroye, D. and R. Freeman, (2002) "Does Inequality in Skills Explain Inequality of Earnings Across Advanced Countries?” DP. 552, CEP LSE, London

De la Fuente, A. and R. Doménech (2000). "Human capital in growth regressions: how much difference does data quality make?" CEPR Discussion Paper no. 2466.

Eurostat (2000) "Imputation of Income in the ECHP", ECHP Documentation, DocPAN 164/2000, Eurostat, Luxembourg.

Eurostat (1996) The European Community Household Panel (ECHP): Survey methodology and implementation, Theme 3, Series E, Eurostat, Luxembourg.

Freeman R. and J. Medoff (1984), What Do Unions Do?, Basic Books: New York,

Freeman (1980), "Unionism and the Dispersion of Wages," Industrial and Labor Relations Review, 1980, 34(1): 3-23.

Gosling, A. Machin, S. and Meghir, C. (1996) "What has happened to the wages of men since 1966?", in Hills (ed), New Inequalities, The Changing Distribution of Income and wealth in the UK, Cambridge University Press, Cambridge UK.

Golden, M., P. Lange, and M. Wallerstein (2002), "Union centralization among advanced industrial societies: An empirical study", Dataset available at http://www.shelley.polisci.ucla.edu/data.

Gottschalk, P. and M. Joyce (1998), "Is earnings inequality also rising in other industrialized countries? the role of institutional constraints", Review of Economics and Statistics, 80 (4), 489-502.

Gottschalk, P. and T. M. Smeeding (1997). Cross-national comparisons of earnings and income inequality, Journal of Economic Literature, 35, 633-687.

Haffner R., Nickell, S., Nicoletti G. and S. Scarpetta (2001) "European integration, liberalisation and labour market performance", in Bertola, Boeri and Nicoletti (eds.) Welfare and Employment in a United Europe, MIT Press, Cambridge, Mass.

Hirsch and Addison (1986), The Economic Analysis of Unions: New Approaches and Evidence, London: Allen and Unwin 
Katz, Lawrence F. and David H. Autor. 1999. "Changes in the Wage Structure and Earnings Inequality." In O. Ashenfelter and D. Card, eds. Handbook of Labor Economics, volume 3, North Holland.

Katz, L.F. and K.M. Murphy, (1992), "Changes in Relative Wages, 1963-87: Supply and Demand Factors.” Quarterly Journal of Economics 107, 35-78.

Koeniger W., Leonardi M. and Nunziata L. (2004), Labour Market Institutions and Inequality, IZA DP No. 1291

Krueger, A. (1993) "How Computers Have Changed the Wage Structure: Evidence From Microdata, 1984-1989, Quarterly Journal of Economics, 108 (1), 33-61.

Juhn, C., Murphy, K. and Pierce, B. (1993) "Wage Inequality and the rise in returns to skill", Journal of Political Economy, 101, 410-42.

Leuven, E., Oosterbeek, H. and van Ophem, H. (2004), 'Explaining International Differences in Male Wage Inequality by Differences in the Demand and Supply of Skill', Economic Journal, 114 (495), 466-486.

Lucifora C. (2000), "Wage Inequality and Low Pay: the Role of Labour Market Institutions", in Gregory, Salverda and Bazen, Labour Market Inequalities, Oxford University Press: Oxford, 9-35.

Machin, S., (1997), "The Decline of Labour Market Institutions and the Rise in Wage Inequality in Britain” European Economic Review, Paper and Proceedings, 41, 647 658.

Machin, S. and Manning, A. (1994), "Minimum Wages, Wage Dispersion and Employment: Evidence From The UK Wages Councils", Industrial and Labour Relations Review, 47, 319-329.

Machin, S., and J. Van Reenen, (1998), "Technology and Changes in Skill Structure: Evidence from Seven OECD Countries," Quarterly Journal of Economics, 113, 12151244.

Manning, A. (1995). "How Do We Know That Real Wages Are Too High?", Quarterly Journal of Economics, 110(4), 1111-25.

Moene, K. O. and M. Wallerstein (1997): "Pay inequality” Journal of Labor Economics 15, 1997. pp. 403-430

Murnane, R.J., Willet, J.B., and Levy, F. (1995) "The Growing Importance of Cognitive Skills in Wage Determination." Review of Economics and Statistics , 77, 251-266.

Nickell, S. and Layard, R., (1999), "Labor market institutions and economic performance", in O. Ashenfelter and D. Card (eds.), Handbook of Labor Economics, vol.3 (46), Elsevier, 3029-3084

Nickell, S. and B. Bell (1996). Changes in the distribution of wages and unemployment in OECD countries. American Economic Review, Papers and Proceedings 86 (2), 302308.

Nickell, S., Nunziata, L. and Ochel W. (2004), “Unemployment in the OECD since the '60. What do we know?", Economic Journal, 115, 1-27. 
OECD (1996), Employment Outlook, Organization for Economic Cooperation and Development: Paris.

OECD (2003), Employment Outlook, Organization for Economic Cooperation and Development: Paris.

OECD (2004), Employment Outlook, Organization for Economic Cooperation and Development: Paris.

OECD (2005), Education at a Glance, Organization for Economic Cooperation and Development: Paris.

OECD (1995), OECD Education Statistics 1985-92, Organization for Economic Cooperation and Development: Paris.

Osterman P. (2000), "Work Reorganization in an Era of Restructuring: Trends in Diffusion and Effects on Employee Welfare", Industrial and Labor Relations Review, 53 (2), $179-196$

Peracchi F. (2002) "The European Community Household Panel: A review", Empirical Economics 27, pp. 63-90.

Tinbergen, J., (1952), On the Theory of Economic Policy, Amsterdam, North-Holland.

Visser, J., (2000), “A Combined Indicator of Union Centralisation and Coordination", Amsterdam Institute for Advanced Labour Studies, Working paper 00/3, Amsterdam.

Wallerstein (1990), "Centralized Bargaining and Wage Restraint", American Journal of Political Science, 43, 982-1004.

Wallerstein, M. (1999) "Wage-setting institutions and pay inequality in advanced industrial societies", American Journal of Political Science, 43 (3), 649-80. 


\section{DATA APPENDIX}

\section{A1 - Primary Data: EDWIN and ECHP samples}

Our primary data is based on national data sets for 8 of the 9 countries that participated in the EDWIN project, namely: Finland, France, Germany, Greece, Italy, Norway, Sweden and the United Kingdom. Through EDWIN partners we had access to information on individual workers from different data sets with more than 1.4 million observations. The data sources and the years of observation, ranging from the mid 1970s to 2003 (but varying by country), are indicated below. When information on earnings was not available from Labour Force Surveys we used other comparable sources (as indicated below). The definition of earnings is "gross hourly earnings", except for Greece and Italy for which only net hourly earnings (after income taxes and social security contributions) were available.

Finland: Labour Force Survey, 1984 to 2002 (supplemented with income data from the tax registers); France: Labour Force Survey/Enquète Emploi, 1983 to 2001;

Germany: German Socio-Economic Panel, 1984 to 2002;

Greece: Labour Force Survey, 1987 to 2002 and Household Budget Survey 1974 to 1999

Italy: Labour Force Survey, 1978 to 2001 and Survey of Households' Income and Wealth, 1987 to 2002;

Norway: Labour Force Survey, 1975 to 2002 and Level of Living Survey 1980 to 2002;

Sweden: Labour Force Survey, 1986 to 2002 and Level of Living Survey 1974 to 2000;

UK: Labour Force Survey 1980 to 2003, and General Household Survey 1994 to 2003.

Education is defined by level of education using the ISCED-97 classification to obtain a cross-country comparable classification: primary education (including lower secondary education), upper secondary education and tertiary education. The results of the estimation from our primary data set, by level of education, constitute what we have labelled the EDWIN sample.

We complemented the available "primary" information using micro data from the European Community Household Panel (ECHP) -- from 1994 to 2000 -- for Austria, Belgium, Denmark, Finland, France, Greece, Italy, and Spain. Throughout the paper we label this the ECHP sample.

\section{A2 - Secondary Data}

The secondary data set consists of 117 observations of estimated wage premia drawn from quantile regressions separately fitted for each year and primary data set.

Additional labour force information (population, labour force, employment, etc.) are obtained from national Labour force surveys, primary data sets (listed above) and other sources (De la Fuente, 2004; OECD, 2005). The definition of variables is reported in the table below.

Table A1 - Variables definitions

\begin{tabular}{|c|c|}
\hline Variables & Definition \\
\hline Ln wage(Tertiary/Primary) (1) & $\begin{array}{l}\text { Log wage premium for the median worker of obtaining tertiary education relative to } \\
\text { primary education (i.e. median return to tertiary education) }\end{array}$ \\
\hline Ln wage(Secondary/Primary) (1) & $\begin{array}{l}\text { Log wage premium for the median worker of obtaining secondary education relative to } \\
\text { primary education (i.e. median return to secondary education) }\end{array}$ \\
\hline Q9010 (2) & $\begin{array}{l}\text { Inter-quantile range }\left(90^{\text {th }} \text { percentile and } 10^{\text {th }} \text { percentile) of expected wages conditional }\right. \\
\text { on a given level of education (i.e. } \log \left[\text { predicted wage } 9^{\text {th }} \text { decile } / 1^{\text {st }} \text { decile] for tertiary, }\right. \\
\text { secondary and primary level) }\end{array}$ \\
\hline Q9050 (2) & $\begin{array}{l}\text { As above (i.e. log[predicted wage } 9^{\text {th }} \text { decile } / 5^{\text {th }} \text { decile] for tertiary, secondary and } \\
\text { primary level) }\end{array}$ \\
\hline Q5010 (2) & $\begin{array}{l}\text { As above (i.e. } \log \left[\text { predicted wage } 5^{\text {th }} \text { decile } / 1^{\text {st }} \text { decile] for tertiary, secondary and }\right. \\
\text { primary level) }\end{array}$ \\
\hline Vet supply shifter (3) & Predicted (net) relative demand and relative supply \\
\hline Ln(Tertiary Population Share) (4) & Log population shares of tertiary education \\
\hline Ln(T/P) Labour Force (5) & Log relative share in the labour forc \\
\hline (T/P)_Employment (5) & Log relative employment rates for tertiary relative to primary education \\
\hline
\end{tabular}

Note: (1) estimated from a quantile regression model of log hourly wage, controlling for educational level, gender, age, age square, private sector and manufacturing.

(2) our reference person within each educational group is: male, 40 years of age, working private sector manufacturing as

(3) obtained from model 1 in tab. 5.1, and model IV in Tab. 5.3.

(4) from OECD (2005), De la Fuente (2004),

(5) from the population shares (above) and information on participation, and employment shares from the primary data sets as well as national Labour force surveys. Similar variables are constructed for the share of secondary education relative to primary. 


\section{A3 - Labour Market Institutions Data}

Institutional variables are also drawn from various sources (Golden, Lange and Wallerstein, 2002; and the OECD).

\section{Employment Protection}

Blanchard and Wolfers (2000) provide an employment protection time varying variable from 1960 to 1995, each observation taken every 5 years. Then updated with OECD data from 1985 onward. This dataset includes an interpolation of the Blanchard and Wolfers series. Range is $\{0,10\}$ increasing with strictness of employment protection (i.e. 0 is no protection while 10 represents the highest level ). This measure of employment protection takes into account the different components which may contribute to the relative strictness of job protection schemes, namely: protection on regular jobs (severance payment, advance notice, "justa causa", etc.); terms and conditions on temporary employment (fixed term contracts, termination rules in non-regular jobs), and the role of intermediation agencies (OECD, 1999).

\section{Union Density}

This variable is constructed as the ratio of Total Reported Union Members (net of retired and unemployed members), on Wage and Salaried Employees (Visser, 1996; and Golden, Lange and Wallerstein (2002) data set).

\section{Bargaining Coordination}

This is an index with range $\{0,10\}$ constructed as an interpolation of OECD data on bargaining coordination. It is increasing in the degree of coordination in the bargaining process on the employers' as well as on the unions' side (i.e. 0 is decentralised wage setting and 10 represents complete national negotiations). The series are drawn from the Golden, Lange and Wallerstein (2002) data set supplemented with data from OECD.

\section{Replacement Ratio}

Replacement Ratios for unemployment benefits is drawn from OECD institutional data. The index range is $\{0,10\}$, where 0 is the lowest level of unemployment benefits, while 10 represents the highest level. The data refers to first year of unemployment benefits, averaged over family types of recipients, since in many countries benefits are distributed according to family composition.

\section{Public expenditure on tertiary education}

Total expenditures on tertiary education (from OECD data). 